\title{
Mechanisms of immunosuppression by mesenchymal stromal cells: a review with a focus on molecules
}

\author{
Kazuhisa Nishizawa* and Reiko Seki \\ Department of Clinical Laboratory Science, Teikyo University, Japan
}

\begin{abstract}
Immunosuppressive treatment with mesenchymal stromal (stem) cells (MSCs) has been performed in many human transplantation settings with the goal to prevent rejection. The therapeutic potential of MSCs has also been explored in a broad spectrum of applications including the treatment of autoimmune diseases. As the immunomodulatory function of MSCs is a multifactorial process, it is important to occasionally review the precise molecular mechanisms/modalities and insights into how they are orchestrated and deployed in clinical settings. This article aimed to review the mechanisms of the immunosuppressive activities of MSCs from a molecular (modality) perspective, with an emphasis on recent reports published between 2014 and mid 2016. The article highlights the subtle differences due to cell type, timing, and types of priming that could lead to better quality control and pre-enhancement of MSCs to optimize their therapeutic potential.
\end{abstract}

\section{MSCs and their immunomodulatory capabilities}

Adult MSCs have been proposed to be a potential therapeutic alternative for inflammatory diseases and tissue transplantation, based on their capacity to modulate the function of most types of immune cells [1]. MSCs are a heterogeneous population of cells that were originally isolated from bone marrow as progenitor cells of the osteogenic lineage by Friedenstein [2]. Although first isolated from bone marrow, now MSCs can be obtained from other adult and fetal sources, including adipose [3], dental pulp [4], and the umbilical cord [5] tissues. The ability of MSCs to differentiate into adipocytes, chondrocytes, and osteoblasts is also well documented [6]. MSCs are characterized by their proliferation on plastic-adherents in a culture, their fibroblast-like shape, and their expression of stromal markers such as CD105, CD73, and CD90, and not hematopoietic markers including CD45, CD34, CD14 (or CD11b), CD79alpha (or CD19), or human leukocyte antigen (HLA)-DR molecules. Among the mammals, the expression of CD105 is variable, but CD45 was found to be absent across species tested by $\mathrm{Su}$ et al. [7].

A more formal definition of MSCs could be the one proposed by the International Society for Cellular Therapy [8-10]. A population of MSCs has the following features:

1) They are plastic-adherent when cultured using standard protocols.

2) Phenotypically, ex vivo generated MSCs express a number of nonspecific markers including CD105 (SH2 or endoglin), CD73 (SH3 or SH4), CD90, CD166, CD44, and CD29. MSCs do not express hematopoietic and endothelial markers such as CD11b, CD14, CD31, and CD45 (of note, CD106 may be included).

3) MSCs can be differentiated into bone, fat, and cartilage tissue with the appropriate stimulation.

Significantly, MSCs have multilineage potential and immunomodulatory capacity [11]. Bartholomew et al. [12] showed that intravenous administration of donor MSCs to MHC-mismatched recipient baboons caused prolonged survival of third-party skin grafts. In an analysis of MSC immunogenicity, Tse et al. [13] reported that MSCs do not elicit an allogeneic proliferative response, and furthermore that MSCs are capable of suppressing allogeneic $\mathrm{T}$ cell proliferation through third party peripheral blood mononuclear cells (PBMCs).

Studies on MSCs led to the consensus that the beneficial effects of MSCs on immune cells include not only the inhibition of proinflammatory polarization [14], and effector functions and pathways [15-17], but also the generation of regulatory cells $[18,19]$. Leukocyte subpopulations including regulatory $\mathrm{T}$ cells, type-2 macrophages, immature dendritic cells (DCs) are now well known to exert immunosuppressive effects; however, MSCs can induce and collaborate with these cells. Thus, MSCs are able to induce peripheral tolerance, which shows their potential as therapeutic tools for immunemediated disorders including graft-versus-host disease (GVHD).

Furthermore, MSCs are known to exhibit low-level expression of MHC-I (major histocompatibility complex-1) proteins and lack the expression of MHC-II and co-stimulatory molecules CD80, CD86, and CD40. Owing to this feature, MSCs are not able to trigger T cell activation [12]. In addition, MSCs can inhibit the proliferation of allostimulated $\mathrm{T}$ cells and both $\mathrm{CD}^{+}$and $\mathrm{CD} 8^{+}$phytohemagglutininstimulated human $\mathrm{T}$ cells [20] and induce the proliferation of Treg cells $[21,22]$. In vitro co-culture of T cells with MSCs results in a shift towards a CD $4^{+} \mathrm{CD} 25^{+}$Foxp $3^{+}$Treg phenotype. Other than T cells [23], MSCs have been shown to exert strong inhibitory effects on a variety of immune cells including B cells [24,25], NK cells [26], and dendritic cells (DCs) $[11,27,28]$.

Reflecting recent preclinical and clinical research activities using

Correspondence to: Kazuhisa Nishizawa, Department of Clinical Laboratory Science, Teikyo University, Japan, Tel: +81-3-3964-1211, ext: 46136, E-mail: kazunet@med.teikyo-u.ac.jp

Received: May 24, 2016; Accepted: July 20, 2016; Published: July 23, 2016 
MSCs, a substantial number of recent review articles appear to have focused on challenges associated with the quality control of MSCs for therapeutic use. As Galipeau and Krampera [29] suggest, robust markers and assays that result in the approval and release of MSCs as commercial products need to be established. The current research is focused on a better understanding of the immunoregulatory properties of MSCs with the ultimate goal of establishing clinically useful methods for quality control. Recent review articles covering preclinical and clinical challenges include that of Gao et al. [1].

The molecular mechanisms mediating the anti-inflammatory function of MSCs have been the focus of intense study. Soluble and cell-bound factors identified to have a role in mediating this function include transforming growth factor (TGF- $\beta$ ), nitric oxide (NO), indoleamine 2,3-dioxygenase (IDO), prostaglandin E2 (PGE2), hepatocyte growth factor (HGF), IL-6, Notch-receptors, human leukocyte antigen (HLA-G), and programmed cell-death ligand 1 (PD-1). However, MSCs generally exhibit context-dependency, which suggests that caution needs to be exercised when extrapolating In vitro or in vivo phenomena, including data regarding different diseases as well as diverse host and donor backgrounds. Given the preclinical and clinical challenges, such molecular mechanisms might be better reviewed by focusing not only on positive but also negative findings.

This article focuses on recent (in particular 2014 to mid-2016) findings about the immunosuppressive molecules expressed by MSCs. Recent review articles focusing on these various molecules include English [30], Shi et al. [31], and Uccelli et al. [11]. We acknowledge that our coverage is limited to a few selected papers allowing us to focus on details for each molecule.

\section{IDO}

MSCs can be viewed as sensors and switches of inflammation, deploying a variety of factors to alter the course of immune reactions [32]. Among the factors that are upregulated de novo in response to an inflammatory environment and function to alter effector pathways, IDO1 has been considered to play a pivotal and central role [33]. IDO inhibits $\mathrm{T}$ cell growth and function via the degradation of tryptophan, an amino acid essential for lymphocyte proliferation and evasion of apoptosis. Furthermore, IDO also catabolizes tryptophan into toxic metabolites including kynurenine [34]. At least for adipose-derived MSCs, tryptophan depletion rather than kynurenine accumulation was shown to be more important for IDO-mediated T lymphocyte inhibition [35]. Mammalian species can be divided into at least two distinct groups, specifically, IDO utilizers and iNOS utilizers. MSCs from monkeys, pigs, and humans employ IDO to suppress immune responses, whereas MSCs from mice, rats, rabbits, and hamsters use iNOS [7]

Molecules that function at a relatively short distance should become effective only when target cells are in the vicinity of the MSCs. In general, activation of $\mathrm{T}$ cells produces an IFN- $\gamma$ gradient, which mobilizes MSCs toward areas of inflammation [36] and induces the expression of IDO [37]. Recent studies by Di Trapani et al. [38,39] implicated IDO as a major determinant of suppressive effects. Their experiment using an IDO-inhibitor (L-1-methyltryptophan or L-1MT) showed that IDO is a major determinant of the anti-proliferative effects that MSCs have on T cells. Using inhibitors against COX-2 and HO-1, minor roles for the latter molecules in the anti-proliferative effects of SCs were shown. Hong et al. [40] showed that IFN- $\gamma$-induced IDO expression mediates the suppression of proliferation not only in an allogeneic mixed lymphocyte reaction (MLR) system but also in viral antigen specific CD8 ${ }^{+} \mathrm{T}$ cells. An effect of IDO from MSCs in mediating the induction of regulatory $\mathrm{T}$ cells has also been shown $[41,42]$.

Recently, several studies have focused on the role of IDO in Crohn's disease. Mucosal $\mathrm{T}$ cell abnormalities have been implicated in the pathogenesis of inflammatory bowel diseases (IBDs) involving Crohn's disease. Mucosal T cells in Crohn's disease patients, compared to those of ulcerative colitis and control patients, which showed resistance to apoptotic signals [43]. In a study conducted by Ciccocioppo et al. [44] on Crohn's disease, biopsies from the inflamed and non-inflamed mucosa of patients and from the healthy mucosa of control subjects were used. Cells present in the epithelium, i.e., a population composed of monocytes, macrophages, T and B lymphocytes, NK cells, DCs, myofibroblasts, and granulocytes, were sampled and mononuclear cells were co-cultured with or without allogeneic MSCs. Immunosuppressive roles of CD69 in the bowel have been well documented [45,46]. T cells from both inflamed and non-inflamed mucosa in Crohn's disease showed a significant reduction in both cell viability and proliferative response to muramyl-dipeptide, a motif on bacterial peptidoglycan recognized by NOD2, of which dysfunction is likely to be associated with Crohn's disease. A reduction in an activated $\mathrm{CD} 4^{+}-\mathrm{CD} 25^{+}$subset and an increase in the regulatory $\mathrm{CD}^{+}-\mathrm{CD} 9^{+}$population were observed when $\mathrm{T}$ cell lines from Crohn's disease mucosa were cocultured with MSCs [44]. This study further demonstrated that the suppressive effects of MSCs are accompanied by cytokine expression patterns that were mostly IDO-dependent, based on the analysis using siRNA and 1-methyl-DL-tryptophan, a specific inhibitor of IDO, while the dysfunction of autophagy has also been observed in Crohn's patients. Chinnadurai et al. [47] showed the importance of MSC-derived IDO, but not autophagy, for the suppression of T cell proliferation in Crohn's patients.

Recent transfection-based studies support the importance of IDO. He et al. [48] reported that transduced IDO increased the direct immunoregulatory properties of MSCs, and in particular, enhanced the expression and function of $\mathrm{CD} 4^{+} \mathrm{CD} 25^{+}$Foxp $3^{+}$Treg cells and induced allograft tolerance. Ebrahimi et al. [49] showed the potential usefulness of IDO in allografts transplantation especially when local but not systemic immunosuppression is required. Specifically, they prepared rat lung tissues using decellularized tissue with MSCs. When IDO-expressing lentivirus-transfected MSCs were used, rat allograft transplantation was more successful than that in control rats based on rejection score and inflammatory cytokine profiles.

Li et al. [50] showed that COX-2, but not IDO-1, expression through electroporation enhanced the immunosuppressive activity of umbilical cord MSCs. However, umbilical cord MSCs differ from BMMSCs, as umbilical cord MSCs are intrinsically immunosuppressive and priming is not effective [51].

\section{Inducible nitric oxide synthase (iNOS) and NO}

NO in high concentrations can inhibit immune responses through largely unidentified mechanisms [52]. As Su et al. [7] reported, rodents, rabbits, and hamsters but not humans, mainly utilize iNOS for immune suppression mediated by MSCs. Upon co-culture of CD3-stimulated human PBMCs and BM-MSCs, NO production was insignificant, and an iNOS inhibitor (NG-monomethyl-L-arginine acetate salt or L-NMMA) had little effect [7].

Regardless of whether the donor species utilized iNOS or IDO, the series of events for immunosuppression by MSCs is likely to be 
as follows; immune cells are recruited into the vicinity of the MSCs via chemokines and are retained by adhesion molecules, and then suppressed mainly by local high concentrations of NO or by IDOmediated tryptophan depletion [53]. iNOS is the sole source of NO in murine MSCs [53]. Stimulation with IFN- $\gamma$ and TNF- $\alpha$, IL-1 $\alpha$ or IL- $1 \beta$ induces the expression of iNOS in mouse MSCs [54]

Intriguingly, NOS activity has been detected in many human tumors. For example, human prostate carcinomas contain tumorinfiltrating lymphocytes (TIL), and peroxynitrates, which are toxic to T lymphocytes, are present in TILs [55]. Inhibition of arginase and NOS reduced tyrosine nitration and restored $\mathrm{T}$ cell functions in tumors [55]. Here, arginase is considered to deplete arginine and trigger the generation of superoxide, which can react with NO to produce peroxynitrates. Although it has not been tested according to us, future genetic engineering of human MSCs might utilize the iNOS gene to potentially enhance the immunosuppressive activity of MSCs.

\section{COX-2/PGE2}

Tse et al. [13] showed that treatment with the COX-inhibitor indomethacin led to partial recovery of T cell proliferation in a PBMC co-culture experiment. Najar et al. [56] showed that indomethacinbased inhibition of PGE2 production led to substantial inhibition of proliferation suppression by MSCs from bone marrow (BM), adipose tissue (AT), and Wharton's jelly (WJ). In addition, induction of Foxp ${ }^{+}$ Treg cells by PGE2 was shown by English et al. [57].

Nemeth et al. [58] showed that BM-MSCs could attenuate sepsis in a mouse sepsis model using the cecal ligation and puncture (CLP) procedure. Analyses using anti-IL-10 and anti-IL-10R antibody administration to CLP mice showed that the beneficial effects of BMMSCs were mediated by IL-10. Macrophages are strongly suggested to be the main source of this increase in IL-10. In culture analysis, LPS-stimulated macrophages produced IL-10, which was enhanced when co-cultured with BM-MSCs (compared to that in those macrophages alone). The latter effect of BM-MSCs was accompanied by COX-2 protein expression in BM-MSCs and was dependent on TLR-4, MyD88, TNFR-1a, and COX-2. Using EP2 and EP4 receptor antagonists In vitro, it was demonstrated that these PGE2 receptors mediate the effects of PGE2. Of note, TLR-4/MyD88 signaling led to nuclear factor kappaB (NF-kB) activation, which is known to induce COX-2 expression in many cell types [59,60]. Intriguingly, Khan et al. [61] showed that WJ-MSCs did not express COX-2 in response to LPS or in response to co-culture with neutrophils, but the combination of LPS and adult neutrophils markedly induced the generation of COX-2 (40-fold induction) in WJ-MSCs [61].

PGE2 can promote the induction of an M2 suppressive phenotype in macrophages [62,63]. For example, Maggini et al. [62] measured PGE2 levels and found that MSCs constitutively produce PGE2 at levels sufficient to inhibit the production of TNF- $\alpha$ and IL- 6 by activated macrophages. Duffy et al. [64] showed that in Th17-skewed cultivation of $\mathrm{CD}^{+} \mathrm{T}$ cells, Th17 induction in both naive and memory T cell populations was inhibited by MSCs, and this was dependent on COX-2 upregulation through direct contact between MSCs and T cells.

Li et al. [50] cultured PBMCs stimulated with phytohemagglutinin (PHA) with umbilical cord-derived MSCs. When MSCs transiently transfected with the COX-2 gene were used, a suppressive effect on lymphocyte proliferation, IFN- $\gamma$ and TNF- $\alpha$ was observed. The suppressive effects of IDO-1 transfection were not as prominent as those with COX-2 in MSCs. The expression of heme-oxygenase-1
(HO-1), iNOS, TNF- $\alpha$-stimulated gene/protein-6 (TSG-6), TGF- $\beta$, $H L A-G 5$, and $I L-10$ were all increased after $C O X-2$ transfection in MSCs. Of note, transfection of IDO-1 led to decreased expression of this set of genes. This data set suggested that PGE2 alone could alter the immunosuppressive state towards a more suppressive one.

Braza et al. [65] performed PKH26 red fluorescent marker labeling of MSCs before intravenous injection into an asthma mouse model. Interestingly, only macrophages that phagocytosed $\mathrm{PKH} 26^{+} \mathrm{MSCs}$, but not those with $\mathrm{PKH} 26^{-}$MSCs, exhibited M2 phenotypes induced by MSCs, suggesting that the suppressive phenotype of M2 was induced by MSC phagocytosis, not by cross-talk between macrophages and MSCs [65]. In the system used by Braza et al. [65], injected MSCs expressed 10- to 100-fold more COX-2 than those before injection. To our knowledge, the molecular mechanism by which this high level of COX-2, induced after phagocytosis, assists the induction of the M2 phenotype is still elusive.

Hermankova et al. [66] analyzed the effects of MSCs on regulatory $\mathrm{B}$ cells, and found that treatment of MSCs with IFN- $\gamma$ increases COX2 expression and can inhibit the development and function of IL-10producing regulatory B cells via the COX-2 pathway. Intriguingly, this result contradicts the general immunosuppressive role of MSCs, but its in vivo relevance is not clear as a highly purified population of cells were used in this study. Other recent studies focusing on PGE2 by Kim, et al. $[67,68]$ showed that subcutaneous application of NOD2-activated human umbilical cord blood-derived MSCs [67] can efficiently ameliorate atopic dermatitis, and the MSC-derived PGE2 and TGF- $\beta 1$ are required for the inhibition of mast cells degranulation [68]. Even from this limited number of studies, we conclude that COX-2/PGE2 might have important roles in this process; further studies are required, especially those utilizing physiological cell populations as well as MSCs derived from non-BM tissues, to confirm these results.

\section{HLA-G}

In humans, unlike classical HLA class Ia (HLA-A, B, C), class Ib (HLA-E, F, G) has low polymorphism [69,70]. HLA-G is a potent tolerogenic molecule, as reviewed by Amiot et al. [71]. Expression of HLA-G is normally limited to a small number of tissues including the cytotrophoblast $[72,73]$, and likely protects the fetus from maternal uterine natural killer cytolysis. HLA-G expression increases in many diseases including cancers, multiple sclerosis, inflammatory diseases, and viral infections and during transplantation [74]. HLA-G neutralizing antibodies can reverse the ability of MSCs to expand CD4 ${ }^{+}$ $\mathrm{CD}_{25}{ }^{+}$Foxp $^{+}$Treg cells In vitro and inhibit the alloproliferative T cell response [75]. HLA-G alters various immune cell functions such as NK cell, cytotoxic $\mathrm{T}$ cell, and allogeneic $\mathrm{T}$ cell proliferation as well as the maturation of DC cells [75]. Morandi et al. [70] also discussed its potential function to affect chemotaxis in T cells and NK cells.

Nasef et al. [76] reported that an antibody-blocking HLA-G molecule increased lymphocyte proliferation in a MSC/MLR system. Rizzo et al. [77] showed a significant correlation between HLA-G and IL-10 upregulation in MSC/PBMC/PHA culture supernatants and lymphoproliferative inhibition. Experiments with monoclonal Antibodies against HLA-G and IL-10 confirmed the inhibitory ability of HLA-G.

The primary transcript of $H L A-G$ is spliced into seven alternative mRNAs encoding membrane-bound (HLA-G1, G2, G3, G4) and soluble protein isoforms [72]. Selmani et al. [75] showed that MSCs express HLA-G5 as a soluble protein, and using a neutralizing 
antibody, they showed that HLA-G5 protects MSCs and neighbor cells from NK cytolysis and inhibits IFN- $\gamma$ secretion by NK cells. The antiHLA-G5 antibody largely reversed most MSC activity to suppress the alloproliferation of $\mathrm{T}$ cells and significantly reduce the expansion of Treg cells.

So far, three HLA-G receptors have been reported; KIR2DL4/ CD158d is expressed on NK cells, LILRB2/ILT-4/CD85d is specific to myeloid lineage cells, and LILRB1/ILT-2/CD85j is expressed by monocytes, dendritic cells, T cells, B cells, and NK cells. Rebmann et al. [78] examined HLA-G-bearing extracellular vesicles. It is of note that LILRB1 interacts with HLA-G molecules associated with $\beta 2 \mathrm{~m}$, whereas LILRB2 specifically recognizes $\beta 2 \mathrm{~m}$-free HLA-G. HLA-G is also recognized by KIR2DL4. HLA-G has been shown to trigger apoptosis in CD8 T and NK cells, as well as CD160 endothelial cells. However, the lack of an appropriate murine model, because mice have no HLA-G, hinders investigations of the in vivo function and significance of HLA-G in pathophysiology.

HLA-G expression is maintained after osteodifferentiation $[79,80]$. Future directions could include the expression profiling of such immunomodulatory molecules at diverse differentiation stages of MSCs from different sources.

\section{Adenosine}

CD39 is an ecto-enzyme that catalyzes the conversion of ATP to $5^{\prime}$ AMP, the substrate for CD73. CD73 catalyzes the reaction that produces adenosine from 5'-AMP. Adenosine is an immunosuppressant that acts mainly through its receptor A(2a) (ADORA2A); upon adenosine binding, this receptor increases intracellular cAMP levels and suppresses T cell functions [81].

Saldanha-Araujo et al. [82] showed that the co-culture led to an increase in the percentage of human BM-MSCs expressing CD39 and $\mathrm{T}$ lymphocytes expressing CD73, and resulted in higher adenosine levels. MSCs expressed CD73 with and without T cells. Blocking of ADORA2A with a specific inhibitor also showed that this adenosinemediated effect at least partly accounted for the immunosuppressive effect of MSCs. Sattler et al. [83] showed a similar result with mouse MSCs, but anti-TGF- $\beta$ and anti-HGF antibodies did not block the suppressive ability of MSCs. Of note, an A(2a) receptor antagonist SCH58261 or the specific CD39 inhibitor polyoxotungstate 1 blocked MSC-mediated suppression of T cell proliferation almost completely. Thus, adenosine seems to be an important mediator of suppression by MSCs.

\section{TGF- $\beta$}

TGF- $\beta$ is a pleiotropic growth factor that is known to be mainly immunosuppressive [23]. Although a TGF- $\beta$ and IL-6 combination promotes differentiation of Th17, TGF- $\beta$ is immunosuppressive in many settings. Among three isoforms, TGF- $\beta 1$ is important for the immune system. TGF- $\beta$ can induce Tregs via upregulation of Foxp3 expression [23]. However, with a standard co-culture system of MSCs and PBMCs, Tse et al. [13] and Ryan et al. [36] showed no effect after blocking with a TGF- $\beta 1$ antibody. Le Blanc et al. [20] also showed that in a co-culture system with PHA-stimulated lymphocytes, anti-TGF- $\beta$ did not affect the suppressive ability of MSCs.

Recent reports studied TGF- $\beta$ from MSCs including Alawad et al. [84]. Comparing androgen receptor knockout (KO) mice and WT mice, the authors showed that $\mathrm{KO}$ of the androgen receptor (AR) gene decreased the immunomodulatory effects of MSCs on Tregs.
The levels of TGF- $\beta$ were lower in T cells co-cultured with ARKOMSCs than in WT-MSCs. Exposure of ARKO-MSC cells to exogenous active TGF- $\beta$ partially restored the induction of Treg cell expansion by ARKO-MSC cells. This report was preceded by the one by Markel et al. [85], which showed gender-based differences in the production of cytokines by MSCs, and that of Huang et al. [86], which showed that targeting AR improves the self-renewal, migration, and antiinflammatory potential during anti-fibrotic actions. These findings could have important implications for characterizing gender-based differences in autoimmune diseases and could influence the use of androgen replacement therapy for lupus. However, these suggest that full understanding of overall merits and demerits of targeting AR requires further analyses.

The relevance of TGF- $\beta$ in atopic dermatitis was recently discussed by Kim et al. [68], who showed that subcutaneous application of NOD2-activated human umbilical cord blood-MSCs can efficiently ameliorate atopic dermatitis and that MSC-derived PGE2 and TGF- $\beta 1$ are required for the inhibition of mast cell degranulation. A recent study by Wu et al. [87] showed that BM-MSCs from miRNA (miR)-21(-/-) mice exhibited enhanced immunosuppression and greater number of $\mathrm{CD}^{+} \mathrm{Foxp}^{+}$Treg cells compared to wild-type BM-MSCs In vitro and that these effects were was inhibited by anti-TGF- $\beta 1$ antibodies.

Although beyond the scope of this review, TGF- $\beta$ has been implicated in many settings for 'termination of inflammation and tissue repair' and is considered to play important, varied, and contextdependent roles in cancer immunology [23]. The role of MSCs in cancer progression has been the focus of recent studies, with emphasis on the role of TGF- $\beta$ in MSC promotion. For example, Barcellos-deSouza [88] showed that TGF- $\beta$ is a crucial molecule that attracts MSCs to prostate carcinoma as well as tumor stromal components.

\section{TSG-6}

TSG-6 is a $\sim 35 \mathrm{kDa}$ secreted protein composed principally of Link and CUB_C domains. It has multifunctional roles and has been identified as a key mediator of the anti-inflammatory effects of MSCs in models including those of myocardial infarction [89], corneal damage [90], traumatic brain surgery [91], would healing [92], and type I diabetes [93].

In many of the animal models and clinical trials, the cells were intravenously infused. MSCs intravenously infused in mice were rapidly trapped in the lung [94], but nonetheless, they enhanced the repair of many organs/tissues. Lee et al. [89] demonstrated the important aspect that human MSCs improved myocardial infarction at least in part because the cells trapped as emboli in the lungs were induced to produce TSG-6. Lee et al. [89] showed that $83 \%$ of the infused cells were recovered from the lung and $0.04 \%$ were recovered from the infarcted hearts $15 \mathrm{~min}$ after the infusion. Embolization upregulated 451 human transcripts and TSG-6 level was increased by more than 28 -fold. A knockdown experiment with TSG-6 siRNA showed that a considerable part of the beneficial effect of MSCs was through the suppression of matrix metalloproteinase expression, and that reduction of infarct size and improvement of cardiac function was dependent on TSG-6 expression [89]. Roddy et al. [95] showed that TSG-6 mediates the protective effect of systemically administered MSCs (either intraperitoneally or intravenously) in a rat model of corneal injury. In the latter report, knockdown of TSG-6 confirmed the role of TSG-6 in vivo, and the results were further validated by intravenous or topical administration of TSG-6. In a zymosan-induced peritonitis model, zymosan, a TLR2 agonist, stimulated the activation 
of TLR2 and NF-kB signaling in macrophages; in addition, TNF- $\alpha$, secreted by activated macrophages, led to the production of TSG- 6 by MSCs [30].

Choi et al. [96] showed that the effect of TSG-6 on TLR2 signaling was dependent on CD44. Specifically, TSG-6 is likely to limit TLR2 and NF-kB signaling through direct interaction with CD44 on macrophages. CD44 is a cell adhesion molecule and is a receptor for glycosaminoglycan (GAG) and hyaluronan (HA) [97]. Although suppression of CD44 has overall benefits, in several settings, CD44 has been suggested to have an anti-inflammatory role [98]. In a broader perspective, the complexity regarding TSG-6 is likely to arise at least in part due to its role in HA matrix formation or interaction with GAG. It has also been reported that TSG-6-mediated organization of the HA matrix alters the interaction between HA and CD44, which is the principle cell surface receptor of HA that functions in anchoring HA to cell surface [99]. TSG-6 inhibits neutrophil migration by binding CXCL8 through its Link module [100]. Interestingly, it was further demonstrated that TSG- 6 binds to multiple chemokines from both the CC and CXC families, thereby masking GAG-binding sites of the chemokines; furthermore, TSG-6 is likely to mask the availability of GAGs, thus inhibiting chemokine/GAG interactions, and thereby reducing neutrophil infiltration [100]. TSG-6 could be a broadspectrum chemokine binding protein and at the same time a regulator of heparin/HS-binding proteins and could therefore precisely control the expression of chemokines and extracellular matrix GAGs [100].

In a search for anti-scarring strategies, Qi et al. [92] analyzed their wound healing mouse system and found that TSG-6 suppressed TNF- $\gamma$-mediated inflammation, leading to anti-fibrogenic (i.e., low) TGF- $\beta 1 /$ TGF- $\beta 3$ ratios, thereby reducing myofibroblast differentiation and suppressing excessive tissue fibrosis.

Regarding the roles of TSG-6 in tissue repair, Martin et al. [101] showed that the TSG-6-mediated formation of heavy chains (HC) of inter-alpha-inhibitor (IaI HC)-HA complexes was critical for pericellular HA matrix formation. They further suggested that the HC:HA catalytic activity (i.e., TSG-6:HC formation and the subsequent transfer of HC (specifically, HC5) to HA) of TSG-6 is a key factor for matrix assembly and phenotypic activation of fibroblasts [101]. Thus, an interrelationship among TSG-6, HA, and CD44 is likely to be further studied in the near future.

\section{Heme oxygenase}

Heme oxygenase (HO) mediates the degradation of heme to biliverdin and is a rate-limiting enzyme in the metabolic pathway linking heme to bilirubin [102]. Several authors have demonstrated that upregulation of HO-1 plays a crucial role in human MSCs $[103,104]$, but its immunosuppressive role is questioned given several controversial results.

Genetic engineering of MSCs has been attempted [105]. BMMSCs showed generally low activity and viability after infusion in vivo, and this prompted genetic engineering, which was intended to improve viability [106]. Wu et al. [107] used an adenovirus vector to ectopically express $\mathrm{HO}-1$ in a high proportion ( $85 \%$ ) of rat BM-MNCs (BM mononuclear cells). Compared to that of the control BM-MSCs, improved rat liver transplantation outcomes were more pronounced with HO-1 transduced BM-MSCs, which were based on the degree of rejection and the number of apoptotic cells. Serum levels of various cytokines were also profoundly affected by this transduction, with the HO1/BM-MSC group showing a two-fold (or higher) increase in IL-10 levels relative to those of the control MSC group for post-operative day 1 to 28 , after liver transplantation.

However, as Galipeau and coworkers discussed [108], the optimal activity of IDO requires heme as a cofactor; HO-1, which degrades heme, could rather antagonize the activity of IDO [108]. Strikingly, Galipeau and coworkers showed that, contrary to other reports, BMMSCs derived from normal subjects do not express significant levels of HO-1 mRNA or protein beyond background levels during steady state conditions or after priming with IFN- $\gamma$, TNF- $\alpha$, and/or TGF- $\beta$ [108]. Tin protoporphyrin (SnPP), which inhibits HO1 but not IDO1, was shown to have no effects on T cell growth inhibition by MSCs in a standard co-culture system in which anti-CD3/CD28 stimulated PBMCs were cultured with MSCs.

\section{CCL2 - implications for myeloid-derived suppressor cells (MDSCs) and B cells}

Several studies have implicated chemokines including CCL2 in MSC immunomodulatory activities. For the development and progression of experimental autoimmune encephalomyelitis (EAE), in addition to Th1/Th17 cytokines, CCL2/CCR2 interaction maybe necessary [109]. MSCs secrete various metalloproteases, which cleave CCL2, converting the latter to an antagonist of $\mathrm{T}$ cell chemotaxis $[110,111]$. Rafei $[109,111]$ showed that murine EAE is alleviated with autologous MSC treatment. Using CCL2 knockout mice, these authors further showed that this effect is mediated by MSC-derived CCL2 secretion and its subsequent digestion by metalloproteases to an antagonistic form, and that its suppressive effect on Th17 cells causes EAE $[109,111]$.

Lee et al. [112] showed that intravenous infusion of human MSCs blocked the development of experimental autoimmune uveitis (EAU) in a mouse model. Importantly, an increase in MHC class II Ly6 $\mathrm{G}^{\text {low, }}$, Ly6 $\mathrm{C}^{\text {high }}$, and CD11 $\mathrm{b}^{+}$cells, which are known to be monocytic MDSCs, in draining lymph nodes (LNs), was observed. This increase, as well as MSC-dependent amelioration, was shown to be CCL2-dependent based on knockdown analysis. Treatment with human MSCs caused an 80-400-fold increase in mouse iNOS expression in the LNs [112].

As CCL2 has systemic action as a chemokine ligand, many more uncharacterized settings could exist, wherein a gradient of CCL2 levels is important. Intriguingly, Che et al. [113] showed that BM-MSCs from lupus-like mice as well as from SLE patients were impaired in the suppression of normal B cell proliferation and differentiation, and this defect was caused by a reduction in CCL2 levels. The overexpression of CCL2 in lupus MSCs restored their B cell immunoregulatory ability In vitro and ameliorated lupus nephritis in vivo [113].

Of note, Zhou et al. [114] recently showed that in a standard mixed lymphocyte reaction (MLR) system, with a low number of MSCs relative to lymphocytes, MSCs stimulated T cell proliferation. They also showed that CCL2 could be important for MSCs to assume their immunostimulatory state [114]. Considering the fact that CCL2 is a chemokine, the role of CCL2 might largely be through attracting effector cells and assisting the immunoregulatory activities of MSCs.

\section{Notch signaling - implications for tolerogenic DCs}

The ability of MSCs to inhibit the inflammatory response of target cells is greater when in direct contact [115]. English et al. [57] showed that human MSCs expanded Foxp $3^{+}$Treg cells through the release of PGE2 and TGF- $\beta 1$, but this study also indicated a role of signaldependent direct cell contact. These findings supported the idea that 
cell membrane protein-mediated signaling might have a role in the immunosuppressive effects of MSCs. Several studies, including the one conducted by Del Papa et al. [116], have indicated or suggested a role for the Notch signaling pathway as a contact signal involved in MSC modulation of immune responses. Cahill et al. [28], using a Notch-signaling inhibitor (GSI), showed that Notch signaling is required for MSC expansion of $\mathrm{CD} 4^{+} \mathrm{CD} 25^{+}$Foxp $3^{+}$Treg cells. They further showed that MSC induction of tolerogenic DCs required Notch signaling. MSC-educated DCs promoted a regulatory environment. In an ovalbumin (OVA)-sensitized mouse model, MSC therapy reduced the pathology and decreased peribronchial inflammation, whereas with Jagged-1 knockdown, MSCs failed to prevent peribronchial inflammation and bronchial epithelial hypertrophy [28]. Consistent with this, a significant increase in Foxp $3^{+} \mathrm{CD} 4^{+} \mathrm{T}$ cells was observed in the lungs of MSC-treated OVA-sensitized mice, but not in the lungs of mice treated with Jagged-1 knockdown MSCs [28]. This study supports the findings of Liotta et al. [117], which showed that blockage of Notch signaling by a Notch signaling inhibitor or a Jagged-1 neutralizing antibody significantly reduced the capacity of MSCs to inhibit T cell proliferation.

Zhang et al. [118] showed that MSCs could promote CD11b expression in mature DCs and enhance their differentiation into regulatory DCs, and demonstrated Jagged-2 signaling-dependency for the regulation of lymphocyte proliferation [118].

Xishan et al. [119] showed that chondrogenic differentiation or IFN- $\gamma$ pretreatment led to enhanced Jagged-2 expression in MSCs. Intriguingly, RNA knockdown of Jagged-2 caused attenuation of the immunosuppressive activity of adipose-derived MSCs in standard coculture experiments.

\section{ICAM-1 and VCAM-1}

It is important to understand the adhesion molecules that are responsible for MSC-lymphocyte binding. Ren et al. [120] showed that ICAM-1 and VCAM-1 induction in mouse BM-MSCs, using the supernatant of activated $\mathrm{T}$ cells, could be blocked by an anti-IFN- $\gamma$ antibody. Neither anti-TNF- $\alpha$ nor anti-IL-1 $\alpha$ showed this inhibition, but the latter cytokines acted synergistically to induce high expression of ICAM-1 and VCAM-1 in MSCs. ICAM-1-deficient MSCs had a significantly reduced immunosuppressive effect in an OVA-challenged mouse model.

ICAM-1 is likely to have many uncharacterized roles. Using an immune-complex-mediated vasculitis murine model, Jiang et al. [121] showed that MSCs suppressed neutrophil activation. This suppression was due to ICAM-1-dependent engulfment of neutrophils by MSCs. They further showed that MSCs constitutively release SOD3, a soluble extracellular form of superoxide dismutase, which can detoxify the superoxide anion radical. This data suggests that MSCs mount an adaptive antioxidant SOD3 response to protect themselves from the threat of neutrophil oxidative burst.

Of note, after 12-16 passages, human BM-MSCs showed marked downregulation or loss of VCAM-1, ICAM-1, ICAM-2, and CD157 (bone marrow stromal cell antigen 1, which can regulate self-renewal, migration, and osteogenic differentiation) [122], along with chemokine receptors including CCR1, CCR7, CCR9, CXCR4, and CXCR5, while maintaining CD105 and CD90 expression [123]. VCAM-1 could be used as a marker for enriching migratory, multipotent, and proliferative cells from culture-expanded human MSCs [124]

\section{Galectin}

Many immunosuppressive processes are mediated by galectin, which is a lectin protein that recognizes polysaccharide chains; each galectin recognizes various glycoproteins [125]. After several groups reported galectin-1 (Gal-1) expression in human MSCs [126,127], Gal-1 was shown to mediate immunosuppression by MSCs in several settings [128,129]. Lepelletier et al. [128] observed that soluble recombinant NP-1, the main receptor of both Gal-1 and semaphorin$3 \mathrm{~A}$, as well as blocking antibodies against Gal-1 and semaphorin-3A, inhibited the suppressive effect of MSCs on T cell proliferation. Gieseke et al. [129] showed that knockdown of Gal-1 mRNA strongly reduced the inhibitory effect of MSCs on PBMC proliferation through IL-2/ OKT3 stimulation, and on CD4 T cell proliferation in the absence of other cells. Intriguingly, Gal-1 knockdown analysis showed that 'DC' inhibition by MSCs was not via Gal-1. Based on the results from Lepelletier et al. [128] and Gieske et al. [129], Gal-1 should not be regarded just as a component of many molecules that have the additive actions for immunosuppression, but also as a molecule required for other such molecules. The lack of Gal-1 leads to $60-70 \%$ recovery compared with the normal $\mathrm{T}$ cell proliferation and normal PBMC experiments, implying that many molecules depend on Gal-1. Therefore, the cellular machinery acts as an integrated unit, not just through the additive contributions of each molecule.

Gal-1 binding to cell surface glycan can induce cell death, either in its soluble or cell-bound form. In an extension of these observations, Toscano [130] showed that differential a2-6 sialylation of glycoproteins renders Th2 resistant to Gal-1-induced death. Th1 and Th17 had a small amount of a2-6 sialylation and large amounts of peanut agglutinin (PNA)-reactive asialo core-1 O-glycans. It is interesting to note that this function for Gal-1 likely contributes to the function of MSCs in providing protection from autoimmune and allergic diseases through shifting the balance of Th1/Th2 and Th17/Treg phenotypes [30].

However, the in vivo significance of Gal-1 requires further evaluation. Recently, Fajka-Boja et al. [131] showed that MSCs from Gal-1 KO mice had similar effects on In vitro $\mathrm{T}$ cell proliferation and on in vivo amelioration (type I diabetes and delayed-type hypersensitivity) as MSCs from WT mice. They used light microscopy-based counting after cell staining and reported that proximity is necessary for Gal-1mediated MSC-based T cell inhibition. This supports our assumption that Gal-1 is likely to be a local factor acting only through direct cell contact [131]

\section{IL-10}

As a representative cytokine of immunosuppression, IL-10 should be unsurprisingly important in most in vivo settings where MSCs exert immunosuppression (e.g., see 58 in the section for COX-2). However, when we restrict ourselves to cytokines directly produced by MSCs, its importance becomes less clear. Ryan et al. [36] showed that $I L-10$ mRNA is constitutively high in BM-MSCs and that IFN- $\gamma$ pretreatment did not change its expression. Notably, neutralization of these soluble factors (IL-10, TGF- $\beta 1$ and HGF) either alone or in combination failed to prevent MSC-mediated suppression in a standard MLR based on co-culture with PBMCs. Redundancy in the suppressive mechanisms or other mechanisms might have to take precedence to exert their functions [36]. In a blocking experiment by Rizzo et al. [77; see above HLA-G section], the importance of HLA-G, but not IL-10, in MSC/PBMC/PHA culture supernatants was shown, despite the presence of both factors. Kim et al. [67] demonstrated that co-culture of human umbilical cord blood-derived (hUCB-) MSCs with human 
mononuclear cells led to elevated IL-10 levels in co-culture media, but hUCB-MSCs themselves did not secrete sufficient levels of IL-10 to exert any immunoregulatory response.

\section{HGF}

In a standard coculture of MSCs of allogeneic PMBC, Ryan et al. [36] performed HGF blocking, but the effect on suppressive ability of MSCs was negative. Le Blanc et al. [20] also reported the suppressive effect of MSCs in coculture with PHA-stimulated lymphocytes wan not influenced by the addition of anti-HGF [20]. However, HGF expression level is constitutively high with WJ-MSCs and low with MB-MSCs [132]. It is possible that MSCs derived from some of non-BM tissues could have high HGF expression.

Yen et al. [133] showed expansion of CD14 CD11 $\mathrm{b}^{+} \mathrm{CD} 33^{+}$MDSCs cells from human peripheral blood lymphocytes (PBLs) by human MSCs from BM and placenta. Yen et al. [133] further showed that HGF secreted by MSCs binds to its cognate receptor c-Met on CD14- PBLs. This binding induced phosphorylation of STAT3, which in turn leads to the MDSC expansion. Thus expanded MDSCs are expressing ARG1 and iNOS and inhibit allogeneic lymphocyte proliferation as well as promote Treg proliferation [133]. The authors further showed in Chen et al. [134] that HGF secreted by placenta-derived MSCs rapidly induce human and murine monocytes to acquire immunomodulatory phenotype to suppress $\mathrm{T}$ cell effector function. HGFs modulate IL-10 production in monocytes through ERK1/2 pathway. Thus in vivo, HGF from MSCs may exert suppressive effects through c-Met-mediated stimulation of CD14+ monocytes to regulatory phenotype [134].

Current researchers are focusing on HGF-gene modified MSCs, with several cases showing promising effects of HGF expression [e.g., 135,136]. Also, tissue injury recovery HGF may be particularly beneficial for recovery from tissue injury [137].

\section{PD-L1 and PD-L2}

Several studies including have drawn an attention to the programmed death ligand 1 (PD-1) pathway. Augello et al. [138] showed that co-culturing of BM-MSC with allogeneic splenocytes and PHA increased programmed death ligand 1 (PD-L1) and PD-L2, although only a part of BM-MSCs showed expression due to heterogeneity. Antibodies blocking PD-1, PD-L1 and PD-L2 showed restoration of the $\mathrm{T}$ cell proliferation in the presence of MSCs. Importance of PD-L1 secreted by mouse MSCs is also highlighted by Sheng et al. [139] in the context of IFN- $\gamma$ priming effect (see below). Priming with TNF- $\alpha$ alone showed no PD-L1 increase [139].

Recent studies on the PD-1 or B7 family pathway involves Luan and coworkers $[140,141]$ that showed that PD-L2 was abundantly expressed in human placenta-derived MSCs and promoted placentaderived MSCs immunosuppressive ability on activated T cells. PD-L1 is expressed in placenta-derived MSCs but almost not B7-H4. PDL1 monoclonal antibody significantly restored anti-CD3 antibodystimulated $\mathrm{T}$ cell proliferation in the presence of placenta-derived MSCs.

Of clinical importance, human placenta-derived MSCs strongly suppressed Th17 responses and this required both IL-25 (also known as IL-17E) and PD-L1 [142].

\section{FAS-ligand}

BM-MSCs express Fas (Apo-1/CD95) ligand (FasL) and activated $\mathrm{T}$ cells express elevated levels of FAS. In Akiyama et al. [143], the authors used $\mathrm{Fasl}^{-/-}$mice, lentiviral transfection of Fasl and a FASLneutralizing antibody with a mice system of systemic infusion of BMMSCs. BM-MSCs were capable of inducing T cell apoptosis through the FasL/Fas signaling pathway. They also showed that wild-type BMMSCs, but not fasl $^{-{ }^{--}}$BM-MSCs could ameliorate disease phenotypes in the mice models of fibrillin-1 mutated systemic sclerosis (SS) and dextran-sulfate-sodium-induced experimental colitis.

$\mathrm{Gu}$ et al. [144] showed that human placenta-MSCs (hPMSCs) constituently expressed PD-L1 and FasL molecules. Both anti-PD-L1 and anti-FasL antibodies partially but significantly reversed the suppressive effects of hPMSCs on PHA or allogeneic PBMC induced T cell proliferation. Intriguingly, the effects of the two antibodies on early $\mathrm{T}$ cell activation measured by CD69 expression were different.

\section{microRNA}

An increasing number of studies are focusing on involvement of microRNAs (miRs) in the regulation of several immune responses in both innate and acquired immunity [11]. Association of miRs with developmental stages of MSCs is under intensive investigations, and on the other hand, considerable attentions are directed to extracellular vesicles that can transfer miRs to other cells $[145,146]$.

Systemic administration of MSCs can ameliorate sepsis in clinical relevant models of sepsis [58]. In these studies the protective effects of MSCs were mainly attributed to the properties mediated by COX-2/PGE2 and IL-10. In an analysis of potential implications of TLRs stimulation for sepsis treatment, Zhao et al. [147] observed that treatment of MSCs with TLR3 ligand, poly(I:C), increased the production of soluble immunosuppressive factors, including COX-2, and the inhibitory effect of MSCs on macrophages through decreasing the expression of miR-143. They showed that TGF- $\beta$-activated kinase- 1 (TAK1) and COX-2 are downregulated by overexpression of miR-143 in MSCs.

Levels of pro-inflammatory cytokines in placental MSCs from preeclampsia (PE) patients have been shown to be higher than in ones from normal women [148]. Wang et al. [149] and Chen et al. [150] showed miR-16 and miR-494, respectively, could inhibit the proliferation and migration of MSCs from severe PE patients. In Wang et al. [149], for example, increased expression of miR-16 in decidua-derived MSCs from severe PE patients relative to normal patients was observed. In their transfection analysis, over-expressed miR-16 inhibited the proliferation and migration of decidua-derived MSCs and induced cell-cycle arrest by targeting cyclin E1.

Importantly, miR-181a expression was also high in placenta from sever PE cases [151]. Overexpression experiments blocked TGF- $\beta$ signaling and further analysis suggested that miR-181a binds to 3'UTR of TGFBR1 and TGFBRAP1 transcripts. Although transfection of miR181a increased IDO, this did not reverse the impaired MSCs capability. Impairment of suppressive ability of miR-181a-transfected MSCs were also verified in a colitis model in vivo. Interestingly, Shao et al. [152] showed that estrogen acts to maintain miR-181a levels low in BMMSCs and that this acts to preserve FasL levels in MSCs necessary to induce osteoclast apoptosis.

miR-146a and miR-146b are negative regulators of inflammatory gene expression in numerous cell types, including monocytes, fibroblasts, endothelial, airway smooth muscle and epithelial cells [153]. miR-146a also negatively regulates COX-2 and IL- $1 \beta$ in human airway smooth muscle cells. Inhibition of miR-29a in human BMMSCs augments their immunosuppressive properties [154]. 


\section{Other molecules}

At the time of this writing, the number of newly characterized immunosuppressive molecules of MSCs appears to be still increasing. CD200 is a transmembrane glycoprotein expressed by cells involving vascular endothelial cells, epithelial cells and lymphocytes and its binding to receptor CD200R expressed on DCs, macrophages and mast cells lead to inmmunosuppresion [155]. In Najar et al. [155], compared to adipose tissue and BM-MSCs, Wharton's jelly MSCs showed higher CD200 expression. IFN- $\gamma$ treatment increased expression in BM-MSCs. However, blocking CD200 - CD200R interaction did not prevent MSCmediated inhibition of lymphocytes proliferation.

CD276 (B7-H3) is a member of the B7 and CD28 families. Normally induced on antigen presenting cells, CD276 plays a role in the inhibition of T cell function [156]. CD276 is highly overexpressed on a wide range of human cancers and likely suppresses immune responses to tumors. La Rocca et al. [80] showed that human Wharton's jelly MSCs maintain the expression of immunomodulatory molecules such as CD276 and HLA-E, F, and G even after the acquisition of a mature phenotype to osteogenic, adipogenic and chondrogenic differentiation.

The effect of PGE2 in MSCs-dependent induction of M2 type macrophages was seen above [65]. Interleukin 1 receptor antagonist (IL1RA) has been shown to mediate immunosuppressive effects of MSCs [157] and, using IL1RA-/- MSCs, Luz-Crawford [158] showed that IL1RA is important to polarize macrophages from M1 to M2 phenotype. MSCs lacking IL1RA were unable to protect mice from arthritic progression and even worsened clinical signs in a collageninduced arthritis murine model, worsening also the balance between Th17 and Treg. [157,158].

IL-6 is produced by various cells and is known to have either pro- or anti-inflammatory effects in different conditions, including increasing or decreasing leukocyte recruitment [159]. Munir et al. [159] showed that IL- 6 and IL-6R are the key mediator of MSCs inhibition of neutrophil adhesion to endothelial cells. Djouad et al. [160] reported that murine MSCs secrete high levels of IL- 6 and vascular endothelial growth factor, which are directly correlated to the inhibition of T-cell proliferation. They also showed that differentiation of bone marrow progenitors into DCs cultured with conditioned supernatants from MSCs was partly inhibited through the secretion of IL-6. So in systemic settings, IL-6 may have propensity to show immunosuppresive effects. However, although coculture of MSCs (derived from BM, Wharton's jelly (WJ), and trabecular bone) with endothelial cells showed IL-6 levels remaining high during passage even after the degree of immunosuppression by MSCs decreased, suggesting that IL- 6 did not act alone in immunosuppression [159]. Thus, interpretation of IL-6 effect is not straightforward due to its diverse functions that show dependence on the context.

Recent analysis by Zanotti et al. [161] showed that angiogenesis and endothelial cell activation is directly inhibited by soluble factors released by MSC exposed to inflammatory cytokines. Proteomics analysis showed that secretion of tissue inhibitor of metalloproteinase-1 (TIMP1) was upregulated in MSC with inflammatory cytokines. In their in vivo and In vitro analyses, this was the key for MSCs-dependent inhibition of endothelial cell activation and lymphocyte homing to lymph nodes.

Nasef et al. [162] reported 7-fold increase in leukemia inhibitory factor (LIF) in MSC/MLR supernatant as compared to MSCs alone. Using LIF neutralizing antibody, a significant restoration of up to $91 \%$ of $\mathrm{CD}^{+}$lymphocyte proliferation in MSC/MLR was observed [162]. Najar et al. [163] showed importance of LIF in AT-derived and WJ derived MSCs suppressive activities.

IL-25 (IL-17E) is also gaining researchers' interest. Human placenta-derived MSCs strongly suppressed Th17 responses and this required IL-25 [142]. Knockdown of IL-25 expression in MSCs abrogated Th17 suppression In vitro and in vivo [142].

\section{MSCs from diverse sources}

MSCs can be obtained from many tissues including umbilical cord [164]. Expression profile analysis by Panepucci et al. [165] suggested that BM-MSCs are more committed to the osteoblastic and adipocytic lineages whereas umbilical cored-derived MSCs would be more committed to angiogenesis, with higher expression of CXCL6, IL-8, IL-1 receptor-like ligand (or IL1RL1LG) and MMP1 (intestinal collagenase) mRNAs. Cell types are also important for immunomodulatory effects. Although we cannot cover many reports, umbilical cord-derived MSCs did not need to be primed with TNF- $\alpha$ and IFN- $\gamma$ to inhibit T cell proliferation in a standard PBMC coculture experiment [51]. For umbilical cord-MSCs, priming with these cytokines were not effective as they have naively potent anti-inflammatory activity in in vivo and In vitro. Relative to BM-MSCs, umbilical cord-MSCs express higher level of CD200, CD273, CD274, IL-1 $\beta$, IL-8, LIF and TGF- $\beta 2$ mRNA and proteins, suggesting that all or some of them are responsible for the potent immunomodulatory ability of umbilical cord MSCs [51].

Systematic comparisons among MSCs from various tissues involve Di Trapani et al. [38]. They showed that all of SCs derived from BM, olfactory ectomesenchymal SCs, and three c-kit positive SC types, that is, leptomeningial SCs, amniotic fluid SCs, cardiac SCs, and lung SCs showed suppressive ability against T, NK and B cells with few exceptions. For most of SCs-effector cells combinations, enhancement of suppressive effects by priming was observed, with the effects on $\mathrm{B}$ cell-SCs combination was relatively pronounced.

Wharton's jelly (WJ)-MSCs are also immmunosuppressive [166]. Prasanna et al. [132] showed that, in their analysis of markers on PHA-stimulated lymphocytes cocultured with WJ-MSCs resulted in an early activation of a negative co-stimulatory molecule, CTLA4, which was not evident with BM-MSCs. Priming was not effective for suppressive ability of WJ-MSCs, but pronounced suppression of MLR responses was observed with primed WJ-MSCs as compared to BMMSCs. Priming with IFN- $\gamma$ and TNF- $\alpha$ was effective in terms of the modulatory molecules induction. Interestingly, HGF is constitutively high with WJ-MSCs (and low with MB-MSCs). TNF-a priming of WJMSCs resulted in marked reduction of HGF secretion [132].

\section{Timing}

To our knowledge, relatively few studies addressed the issue of timing between effector cell stimulations and treatment with MSCs. Valencic et al. [167] examined the timing issue using WJ-MSCs. Human WJ-MSCs cocultured with PBMCs prestimulated with $24 \mathrm{hr}$ with phytohaemagglutinin (PHA) failed to inhibit PBMC proliferation. Licensing by proinflammatory cytokines restored the inhibitory effects of MSCs.

Of importance, Mancheno-Corvo et al. [168] prestimulated human PBMCs with microbeads coated with anti-CD2/CD3/CD28 antibodies. When PBMCs after $6 \mathrm{hr}$ prestimulation were cocultured with adipose MSCs, proliferation was inhibited. Strikingly, adipose MSCs failed to inhibit proliferation of $\mathrm{T}$ cells after $24 \mathrm{hr}$ prestimulation, indicating 
the critical effect of the duration of $\mathrm{T}$ cells prestimulation. They further showed that priming with IFN- $\gamma$ and to a lesser extent with poly (I:C) (TLR3 ligand), but not LPS (TLR4 ligand) and other tested stimuli, enhanced the MSCs ability to inhibit the proliferation of $48 \mathrm{hr}$ stimulated $\mathrm{T}$ lymphocytes. The inhibitory effects of adipose MSCs were time-dependent and accounted for by Trp depletion by IDO.

\section{Priming of MSCs with proinflammatory cytokines}

Although cell types influence immunosuppressive efficacy, it is generally accepted that MSCs such as BM-MSCs need to be activated (or "licensed") with specific pro-inflammatory stimuli to exert their full immunomodulatory potential [169-172]. IFN- $\gamma$ is a major proinflammatory cytokine secreted mainly by activated $\mathrm{T}$ and NK cells [169]. MSCs pretreated with IFN- $\gamma$ could suppress GVHD in a murine model more effectively than a five-fold greater number of nonactivated MSCs [171]. Exposure of MSCs to IFN- $\gamma$ has been reported to upregulate the expression of IDO, TGF- $\beta$ and HGF $[36,169,170]$. Using IFN- $\gamma$ knockout mice and a B7-H1 (PD-L1) knockdown experiment, Sheng et al. [139] presented findings supporting the notion that IFN- $\gamma$ triggers the immunosuppressive function of MSCs via upregulation of B7-H1 expression [139].

In an in situ setting, expression of chemokine receptors including CXCR4, CXCR5, CXCR6, CCR1, CCR7, and CCR9 is considered to enable MSCs to migrate to sites of inflammation [123]. Subsequently, MSCs have to be activated by cytokines (typically IFN- $\gamma$ before they acquire immunosuppressive capabilities [172].

Crop et al. [173] used microarray and RT-PCR analyses to measure several relevant transcripts in adipose tissue-derived MSCs co-cultured with PBMCs with a combination of IFN- $\gamma$, TNF- $\alpha$ and IL- 6 and found that the latter combination increased IDO, whereas there was not much increase in the levels of HLA-G, COX-2 and HGF. MLRs showed an increased expression of COX-2, with a subtle increase in IDO. In a similar experiment by Ryan et al. [36], human MSCs expressed HGF, IL-10, and TGF- $\beta$, but a blocking analysis showed the importance of PGE-2. They showed an increase in HGF, TGF- $\beta 1$, and IDO; however, IDO was important based on their inhibitor analysis.

As we discussed in the section on IDO, through the analysis of adipose MSCs, Mancheno-Corvo et al. [168] showed a key role for IDO-dependent tryptophan depletion in the priming effect of IFN- $\gamma$ and poly (I:C) (TLR3 ligand). They further showed that priming with poly (I:C), but not IFN- $\gamma$, led to increased production of PGE-2. Both IFN- $\gamma$ and poly (I:C) did not result in increased HLA-G. Therefore, it would be interesting to perform systematic comparisons of IFN- $\gamma$, TNF- $\alpha$, Poly(I:C), LPS (TLR4 ligand), and other proinflammatory factors on the expression of various modulatory molecules.

The expression of PD-L2 in human placenta-derived MSCs increased after pre-stimulation with IFN- $\gamma$ and TNF- $\alpha$, and PD-L2 was important for the increase of Treg subsets in co-cultured T cells [141].

\section{TLR agonist pretreatment}

The effect of TLR stimulation on MSCs has been studied with the goal of understanding MSC behavior in clinical settings. The expression of TLRs in MSCs is now well documented. Murine MSCs express TLR1-8, and human MSCs express TLR1-5 [117]. A recent finding proposed that TLR4 ligation could induce a proinflammatory MSC1 response and TLR3 ligation could result in an anti-inflammatory MSC2 response [174]. Sangiorgi et al. [175] showed that TLR4 stimulation by LPS (TLR4 ligand) compromises the ability of MSCs to suppress the proliferation of $\mathrm{T}$ lymphocytes. This pretreatment led to a reduction in $I L-10$ and $I F N-\gamma$ mRNA levels in co-cultured T lymphocytes. Intriguingly, stimulation of TLR9 with DSP30 induced the proliferative and suppressive potential of MSCs. In this system, using human BM-MSCs, approximately $45 \%$ of cells expressed TLR2 and $70-80 \%$ of cells expressed TLR3, TLR4, and TLR9. In addition, TLR3 agonist pretreatment had no effect. It is still a matter of debate whether TLR3 pretreatment reduces or enhances immunosuppression by MSCs [175].

In some settings, stimulation with TLR3 and TLR4 induces IDO in MSCs, but in other settings, the activation of these TLRs inhibits the immunosuppressive effects of MSCs [30]. Careful analyses regarding the precise conditions for IDO induction might be important. Opitz et al. [176] analyzed TLR1-6 expression in human BM-MSCs and found that compared to immature DCs, TLR-3 mRNA levels were similar to that in DCs and that TLR-4 mRNA was lower than that of DCs, whereas differences in the other TLR mRNA levels were insignificant. They further showed that treatment with poly (I:C) (TLR3 ligand) and LPS (TLR4 ligand) increased TLR1-3 expression, strongly and moderately, respectively. Similarly, poly (I:C) treatment and LPS treatment increased kynurenin production, strongly and moderately, respectively. In their system, the enhancement of immunosuppression mediated by TLR was dependent on kynurenines produced by IDO1, the latter enzyme being induced by TLR through signaling pathways independent of IFN- $\gamma$ [176]. However, in a study by Liotta et al. [117], allogeneic proliferation of CD4 ${ }^{+} \mathrm{T}$ cells was suppressed by MSCs, but this suppressive ability was reduced by poly (I:C) pretreatment. Interestingly, the authors argued that Jagged-1 downregulation induced by TLR3 or TLR4 stimulation might have caused the downregulation of the suppressive capability of MSCs. However, Zhao et al. [147] demonstrated the benefits of poly (I:C) treatment for human umbilical cord-derived MSCs in sepsis; the IDO mRNA increase was the most pronounced after a $12 \mathrm{~h}$ treatment, which was greater than that after the $24 \mathrm{~h}$ treatment. Poly (I:C) having a greater effect than LPS on the potential of MSCs was also reviewed by Zhao et al. [147]. In addition, Mancheño-Corvo et al. [168] showed that priming with IFN- $\gamma$ and to a lesser extent poly (I:C), but not LPS and other tested stimuli, enhanced the immunosuppressive ability of adipose-derived MSCs, and convincingly showed that this enhanced ability was time-dependent and was accounted for by tryptophandepletion by IDO. Thus, at least for BM-MSCs and adipocyte-derived MSCs, standard priming or priming with poly (I:C) is likely to enhance the IDO-dependent suppressive effects in a typical In vitro settings. Other groups also reported the benefit of TLR3 preconditioning in a colitis model [177].

Huang et al. [178] used umbilical cord-derived MSCs and reported no enhanced therapeutic effect of poly (I:C)-treated MSCs in an in vivo mouse model of lupus. They observed that poly (I:C) treatment led to no significant changes in COX-2, IL-6, TNF- $\alpha$, IDO, IFN- $\gamma$, and CCL2. However, as umbilical cord-derived MSCs are unlikely to be enhanced by pretreatment [51], such comparisons suggest the importance of better characterization of how differences in parameters including experimental set-up, timing, cell types, and concentrations of ligands could affect the expression of IDO in MSCs.

Using umbilical cord (UC)-MSCs, Zhang et al. [179] found that TLR3 upregulated the expression of stem cell markers, whereas TLR4 downregulated their expression. Intriguingly, the activation of TLR3 inhibited the differentiation of UC-MSCs into osteocytes, whereas that of TLR4 increased this differentiation to a certain extent [179]. As demonstrated by this study, differentiation stages of MSCs are likely 
not to be identical between the two ligand treatments, suggesting another layer of complexity for the effects of TLR pretreatment.

MSCs are able to adapt their immuno-behavior in an inflammatory context, decreasing their susceptibility to NK cells. In addition, TLR3but not TLR4-primed MSCs display enhanced suppressive functions against NK cells [180]. For human umbilical cord blood (hUCB)-MSCs, LPS pre-treatment did not ameliorate the reduction in colon length or the histologic damage, but muramyl dipeptide (MDP) improved the protective effect of hUCB-MSCs against cellular inflammation in the gut via a NOD2-dependent pathway [67]. Thus, further characterization of MSCs derived from various sources, examining a broad range of pattern recognition receptors, could be informative.

\section{Perspective}

As this article focused on immunosuppressive molecules expressed in MSCs, we did not fully cover instances wherein interactions between MSCs and other cell types lead to differential expression patterns of molecules. Several studies have shown that co-culture of MSCs with diverse cells could lead to differential expression of various molecules in MSCs. For example, Fang et al. [181] performed co-culture of human MSCs with alveolar epithelial type II (AT II) cells; AT II cells and MSCs alone generated some amounts of lipoxin $\mathrm{A}_{4}$, a lipid mediator with dual anti-inflammatory and proresolution activities. However, combination of the two cells resulted in significantly higher levels of this molecule. This example, as well as that of the macrophage- MSC interaction reminds us of the difficulty in attributing soluble regulatory molecule production to MSCs and interaction partners.

Genetically engineered MSCs appear to be a promising approach. For example, Wang et al. [182] showed that MSCs engineered to overexpress miRNA-let7c (miR-let7c-MSCs) specifically in damaged kidneys, upregulated miR-let7c gene expression, compared to that in non-targeting control MSCs. This led to the repression of fibrotic genes in NRK52E cells induced by TGF- $\beta 1$. Epstein-Barr virus-derived interleukin-10 (vIL-10) shares some immunosuppressive properties with human IL-10 but lacks immunostimulatory activity. Recently, Quaranta et al. [183] showed that engineering WJ-derived human MSCs to express vIL-10 enhanced the immunosuppressive functions of these MSCs.

From a theoretical perspective, although recent bioinformatics approaches favor systems with deterministic behaviors, the overall features of MSCs behaviors seem to have uncertainty and robustness rather reminiscent of a stochastic (thermodynamic) network. For example, when TGF- $\beta$, COX-2, and IDO expressions are high, a high-HGF state may have a higher likelihood, yet the latter still being influenced by many factors largely unknown. As MSCs behaviors are influenced by their sources, cell heterogeneity, developmental stage, culture condition and between-individual differences, the robustness and sensitivity of the network become important. Blocking analyses with varied degrees of blocking and timing may be informative. On the other hand, to develop assays predictive of immunosuppressive potency and safety required for therapeutics, reduction of such variance needs to be prioritized. As Galipeau and Krampera discussed [29], the use of human PBMC for potency assays, for example, inevitably increases variance but that defining functionalities causative of suppressor function in vivo may allow us to reduce such variance. In this sense, use of IDO-utilizing animals, such as pigs, may provide a complementary system to address immunosuppressive functionalities of MSCs important in in vivo settings.

\section{References}

1. Gao F, Chiu SM, Motan DA, Zhang Z, Chen L, et al. (2016) Mesenchymal stem cells and immunomodulation: current status and future prospects. Cell Death Dis 7: e2062. [Crossref]

2. Friedenstein AJ, Chailakhyan RK, Latsinik NV, Panasyuk AF, Keiliss-Borok IV (1974) Stromal cells responsible for transferring the microenvironment of the hemopoietic tissues. Cloning in vitro and retransplantation in vivo. Transplantation 17: 331-340. [Crossref]

3. Zuk PA, Zhu M, Ashjian P, De Ugarte DA, Huang JI, et al. (2002) Human adipose tissue is a source of multipotent stem cells. Mol Biol Cell 13: 4279-4295. [Crossref]

4. Demircan PC, Sariboyaci AE, Unal ZS, Gacar G, Subasi C, et al. (2011) Immunoregulatory effects of human dental pulp-derived stem cells on $\mathrm{T}$ cells: comparison of transwell co-culture and mixed lymphocyte reaction systems. Cytotherapy 13: 1205-1220. [Crossref]

5. Tondreau T, Meuleman N, Delforge A, Dejeneffe M, Leroy R, et al. (2005) Mesenchymal stem cells derived from CD133-positive cells in mobilized peripheral blood and cord blood: proliferation, Oct4 expression, and plasticity. Stem Cells 23: 1105-1112. [Crossref]

6. James AW (2013) Review of Signaling Pathways Governing MSC Osteogenic and Adipogenic Differentiation. Scientifica (Cairo) 2013: 684736. [Crossref]

7. Su J, Chen X, Huang Y, Li W, Li J, et al. (2014) Phylogenetic distinction of iNOS and IDO function in mesenchymal stem cell-mediated immunosuppression in mammalian species. Cell Death Differ 21: 388-396. [Crossref]

8. Horwitz EM, Le Blanc K, Dominici M, Mueller I, Slaper-Cortenbach I, et al. (2005) Clarification of the nomenclature for MSC: The International Society for Cellular Therapy position statement. Cytotherapy 7: 393-395. [Crossref]

9. Dominici M, Le Blanc K, Mueller I, Slaper-Cortenbach I, Marini F, et al. (2006) Minimal criteria for defining multipotent mesenchymal stromal cells. The International Society for Cellular Therapy position statement. Cytotherapy 8: 315-317. [Crossref]

10. Krampera, M, Galipeau J, Shi Y, Tarte K, Sensebe L (2013) MSC Committee of the International Society for Cellular Therapy (ISCT) . Immunological characterization of multipotent mesenchymal stromal cells The International Society for Cellular Therapy (ISCT) working proposal. Cytotherapy 15: 1054-1061. [Crossref]

11. Uccelli A, de Rosbo NK (2015) The immunomodulatory function of mesenchyma stem cells: mode of action and pathways. Ann N Y Acad Sci 1351: 114-126. [Crossref]

12. Bartholomew A, Sturgeon C, Siatskas M, Ferrer K, McIntosh K, et al. (2002) Mesenchymal stem cells suppress lymphocyte proliferation in vitro and prolong skin graft survival in vivo. Exp Hematol 30: 42-48. [Crossref]

13. Tse WT, Pendleton JD, Beyer WM, Egalka MC, Guinan EC (2003) Suppression of allogeneic T-cell proliferation by human marrow stromal cells: implications in transplantation. Transplantation 75: 389-397. [Crossref]

14. Ghannam S, Pène J, Moquet-Torcy G, Jorgensen C, Yssel H (2010) Mesenchymal stem cells inhibit human Th17 cell differentiation and function and induce a T regulatory cell phenotype. J Immunol 185: 302-312. [Crossref]

15. Uccelli A, Moretta L, Pistoia V (2006) Immunoregulatory function of mesenchymal stem cells. Eur J Immunol 36: 2566-2573. [Crossref]

16. Duffy MM, Ritter T, Ceredig R, Griffin MD (2011) Mesenchymal stem cell effects on T-cell effector pathways. Stem Cell Res Ther 2: 34. [Crossref]

17. Rafei M, Hsieh J, Fortier S, Li M, Yuan S, et al. (2008) Mesenchymal stromal cellderived CCL2 suppresses plasma cell immunoglobulin production via STAT3 inactivation and PAX5 induction. Blood 112: 4991-4998. [Crossref]

18. François M, Romieu-Mourez R, Li M, Galipeau J (2012) Human MSC suppression correlates with cytokine induction of indoleamine 2,3-dioxygenase and bystander M2 macrophage differentiation. Mol Ther 20: 187-195. [Crossref]

19. Najar M, Raicevic G, Fayyad-Kazan H, Bron D, Toungouz M, et al. (2016) Mesenchymal stromal cells and immunomodulation: A gathering of regulatory immune cells. Cytotherapy 18: 160-171. [Crossref]

20. Le Blanc K, Rasmusson I, Götherström C, Seidel C, Sundberg B, et al. (2004) Mesenchymal stem cells inhibit the expression of CD25 (interleukin-2 receptor) and CD38 on phytohaemagglutinin-activated lymphocytes. Scand J Immunol 60: 307-315. [Crossref]

21. Maccario R, Podestà M, Moretta A, Cometa A, Comoli P, et al. (2005) Interaction of human mesenchymal stem cells with cells involved in alloantigen-specific immune response favors the differentiation of $\mathrm{CD} 4+\mathrm{T}$-cell subsets expressing a regulatory/ 
suppressive phenotype. Haematologica 90: 516-525. [Crossref]

22. Di Ianni M, Del Papa B, De Ioanni M, Moretti L, Bonifacio E, et al. (2008) Mesenchymal cells recruit and regulate T regulatory cells. Exp Hematol 36: 309-318. [Crossref]

23. Burr SP, Dazzi F, Garden OA (2013) Mesenchymal stromal cells and regulatory T cells: the Yin and Yang of peripheral tolerance? Immunol Cell Biol 91: 12-18. [Crossref]

24. Asari S, Itakura S, Ferreri K, Liu CP, Kuroda Y, et al. (2009) Mesenchymal stem cells suppress B-cell terminal differentiation. Exp Hematol 37: 604-615. [Crossref]

25. Fan L, Hu C, Chen J, Cen P, Wang J, Li L (2016) Interaction between Mesenchymal Stem Cells and B-Cells. Int J Mol Sci 5: 17. [Crossref]

26. Giuliani M, Oudrhiri N, Noman ZM, Vernochet A, Chouaib S, et al. (2011) Human mesenchymal stem cells derived from induced pluripotent stem cells down-regulate NK-cell cytolytic machinery. Blood 118: 3254-3262. [Crossref]

27. Spaggiari GM, Abdelrazik H, Becchetti F, Moretta L (2009) MSCs inhibit monocytederived DC maturation and function by selectively interfering with the generation of immature DCs: central role of MSC-derived prostaglandin E2. Blood 113: 6576-6583. [Crossref]

28. Cahill EF, Tobin LM, Carty F, Mahon BP, English K (2015) Jagged-1 is required for the expansion of CD4+ CD25+ FoxP3 + regulatory T cells and tolerogenic dendritic cells by murine mesenchymal stromal cells. Stem Cell Res Ther 6: 19. [Crossref]

29. Galipeau J, Krampera M (2015) The challenge of defining mesenchymal stromal cell potency assays and their potential use as release criteria. Cytotherapy 17: 125-127. [Crossref]

30. English K (2013) Mechanisms of mesenchymal stromal cell immunomodulation. Immunol Cell Biol 91: 19-26. [Crossref]

31. Shi Y, Su J, Roberts AI, Shou P, Rabson AB, et al. (2012) How mesenchymal stem cells interact with tissue immune responses. Trends Immunol 33: 136-143. [Crossref]

32. Bernardo ME, Fibbe WE (2013) Mesenchymal stromal cells: sensors and switchers of inflammation. Cell Stem Cell 13: 392-402. [Crossref]

33. Singer NG, Caplan AI (2011) Mesenchymal stem cells: mechanisms of inflammation. Annu Rev Pathol 6: 457-478. [Crossref]

34. Meisel R, Zibert A, Laryea M, Göbel U, Däubener W, et al. (2004) Human bone marrow stromal cells inhibit allogeneic T-cell responses by indoleamine 2,3-dioxygenasemediated tryptophan degradation. Blood 103: 4619-4621. [Crossref]

35. Menta R, Mancheño-Corvo P1, Del Río B1, Ramírez C1, DelaRosa O1, et al. (2014) Tryptophan concentration is the main mediator of the capacity of adipose mesenchymal stromal cells to inhibit T-lymphocyte proliferation in vitro. Cytotherapy 16: 1679-1691. [Crossref]

36. Ryan JM, Barry F, Murphy JM, Mahon BP (2007) Interferon-gamma does not break, but promotes the immunosuppressive capacity of adult human mesenchymal stem cells. Clin Exp Immunol 149: 353-363. [Crossref]

37. DelaRosa O, Lombardo E, Beraza A, Mancheño-Corvo P, Ramirez C, et al. (2009) Requirement of IFN-gamma-mediated indoleamine 2,3-dioxygenase expression in the modulation of lymphocyte proliferation by human adipose-derived stem cells. Tissue Eng Part A 15: 2795-2806. [Crossref]

38. Di Trapani M, Bassi G, Ricciardi M, Fontana E, Bifari F, et al. (2013) Comparative study of immune regulatory properties of stem cells derived from different tissues. Stem Cells Dev 22: 2990-3002. [Crossref]

39. Di Trapani M, Bassi G, Midolo M, Gatti A, Kamga PT, et al. (2016) Differential and transferable modulatory effects of mesenchymal stromal cell-derived extracellular vesicles on T, B and NK cell functions. Sci Rep 6: 24120. [Crossref]

40. Hong J, Hueckelhoven A, Wang L, Schmitt A, Wuchter P, et al. (2016) Indoleamine 2,3-dioxygenase mediates inhibition of virus-specific CD8(+) T cell proliferation by human mesenchymal stromal cells. Cytotherapy 18: 621-629. [Crossref]

41. Fallarino F, Grohmann U, You S, McGrath BC, Cavener DR, et al. (2006) The combined effects of tryptophan starvation and tryptophan catabolites down-regulate $\mathrm{T}$ cell receptor zeta-chain and induce a regulatory phenotype in naive T cells. J Immunol 176: 6752-6761. [Crossref]

42. Ge W, Jiang J, Arp J, Liu W, Garcia B, et al. (2010) Regulatory T-cell generation and kidney allograft tolerance induced by mesenchymal stem cells associated with indoleamine 2,3-dioxygenase expression. Transplantation 90: 1312-1320. [Crossref]

43. Ina K, Itoh J, Fukushima K, Kusugami K, Yamaguchi T, et al. (1999) Resistance of Crohn's disease $\mathrm{T}$ cells to multiple apoptotic signals is associated with a Bcl-2/Bax mucosal imbalance. J Immunol 163: 1081-1090. [Crossref]
44. Ciccocioppo R, Cangemi GC, Kruzliak P, Gallia A, et al. (2015) Ex vivo immunosuppressive effects of mesenchymal stem cells on Crohn's disease mucosal $\mathrm{T}$ cells are largely dependent on indoleamine 2,3-dioxygenase activity and cell-cell contact. Stem Cell Res Ther 6: 137. [Crossref]

45. Shiow LR, Rosen DB, Brdicková N, Xu Y, An J, et al. (2006) CD69 acts downstream of interferon-alpha/beta to inhibit S1P1 and lymphocyte egress from lymphoid organs. Nature 440: 540-544. [Crossref]

46. Radulovic K, Manta C, Rossini V, Holzmann K, Kestler HA, et al. (2012) CD69 regulates type I IFN-induced tolerogenic signals to mucosal CD4 T cells that attenuate their colitogenic potential. J Immunol 188: 2001-2013. [Crossref]

47. Chinnadurai R, Copland IB, Ng S, Garcia M, Prasad M, et al. (2015) Mesenchymal Stromal Cells Derived From Crohn's Patients Deploy Indoleamine 2,3-dioxygenasemediated Immune Suppression, Independent of Autophagy. Mol Ther 23: 1248-1261. [Crossref]

48. He Y, Zhou S, Liu H, Shen B, Zhao H, et al. (2015) Indoleamine 2, 3-Dioxgenase Transfected Mesenchymal Stem Cells Induce Kidney Allograft Tolerance by Increasing the Production and Function of Regulatory T Cells. Transplantation 99: 1829-1838. [Crossref]

49. Ebrahimi A, Kardar GA, Teimoori-Toolabi L, Ghanbari H, Sadroddiny E (2016) Inducible expression of indoleamine 2,3-dioxygenase attenuates acute rejection of tissue-engineered lung allografts in rats. Gene 576: 412-420. [Crossref]

50. Li D, Han Y, Zhuang Y, Fu J, Liu H, et al. (2015) Overexpression of COX-2 but not indoleamine 2,3-dioxygenase-1 enhances the immunosuppressive ability of human umbilical cord-derived mesenchymal stem cells. Int J Mol Med 35: 1309-1316. [Crossref]

51. Bárcia RN, Santos JM, Filipe M, Teixeira M, Martins JP, et al. (2015) What Makes Umbilical Cord Tissue-Derived Mesenchymal Stromal Cells Superior Immunomodulators When Compared to Bone Marrow Derived Mesenchymal Stromal Cells? Stem Cells Int 2015: 583984. [Crossref]

52. Bogdan C (2015) Nitric oxide synthase in innate and adaptive immunity: an update. Trends Immunol 36: 161-178. [Crossref]

53. Li W, Ren G, Huang Y, Su J, Han Y, et al. (2012) Mesenchymal stem cells: a doubleedged sword in regulating immune responses. Cell Death Differ 19: 1505-1513. [Crossref]

54. Ren G, Zhang L, Zhao X, Xu G, Zhang Y, et al. (2008) Mesenchymal stem cellmediated immunosuppression occurs via concerted action of chemokines and nitric oxide. Cell Stem Cell 2: 141-150. [Crossref]

55. Bronte V, Kasic T, Gri G, Gallana K, Borsellino G, et al. (2005) Boosting antitumor responses of T lymphocytes infiltrating human prostate cancers. J Exp Med 201: 12571268. [Crossref]

56. Najar M, Raicevic G, Boufker HI, Fayyad Kazan H, De Bruyn C, et al. (2010) Mesenchymal stromal cells use PGE2 to modulate activation and proliferation of lymphocyte subsets: Combined comparison of adipose tissue, Wharton's Jelly and bone marrow sources. Cell Immunol 264: 171-179. [Crossref]

57. English K, Ryan JM, Tobin L, Murphy MJ, Barry FP, et al. (2009) Cell contact prostaglandin $\mathrm{E}(2)$ and transforming growth factor beta 1 play non-redundant roles in human mesenchymal stem cell induction of CD4+CD25(High) forkhead box P3+ regulatory T cells. Clin Exp Immunol 156: 149-160. [Crossref]

58. Németh K1, Leelahavanichkul A, Yuen PS, Mayer B, Parmelee A, et al. (2009) Bone marrow stromal cells attenuate sepsis via prostaglandin $\mathrm{E}(2)$-dependent reprogramming of host macrophages to increase their interleukin-10 production. Nat Med 15: 42-49. [Crossref]

59. Nakao S, Ogtata Y, Shimizu E, Yamazaki M, Furuyama S, et al. (2002) Tumor necrosis factor alpha (TNF-alpha)-induced prostaglandin E2 release is mediated by the activation of cyclooxygenase-2 (COX-2) transcription via NFkappaB in human gingival fibroblasts. Mol Cell Biochem 238: 11-18. [Crossref]

60. Kirkby NS, Zaiss AK, Wright WR, Jiao J, Chan MV, et al. (2013) Differential COX2 induction by viral and bacterial PAMPs: Consequences for cytokine and interferon responses and implications for anti-viral COX-2 directed therapies. Biochem Biophys Res Commun 438: 249-256. [Crossref]

61. Khan I, Zhang L, Mohammed M, Archer FE, Abukharmah J, et al. (2014) Effects of Wharton's jelly-derived mesenchymal stem cells on neonatal neutrophils. $J$ Inflamm Res 8: 1-8. [Crossref]

62. Maggini J, Mirkin G, Bognanni I, Holmberg J, Piazzón IM, et al. (2010) Mouse bone marrow-derived mesenchymal stromal cells turn activated macrophages into a regulatory-like profile. PLoS One 5: e9252. [Crossref] 
63. Chiossone L, Conte R, Spaggiari GM, Serra M, Romei C, et al. (2016) Mesenchymal Stromal Cells Induce Peculiar Alternatively Activated Macrophages Capable of Dampening Both Innate and Adaptive Immune Responses. Stem Cells 34: 1909-1921. [Crossref]

64. Duffy MM, Pindjakova J, Hanley SA, McCarthy C, Weidhofer GA, et al. (2011) Mesenchymal stem cell inhibition of T-helper 17 cell- differentiation is triggered by cell-cell contact and mediated by prostaglandin E2 via the EP4 receptor. Eur J Immunol 41: 2840-2851. [Crossref]

65. Braza F, Dirou S, Forest V, Sauzeau V, Hassoun D, et al. (2016) Mesenchymal Stem Cells Induce Suppressive Macrophages Through Phagocytosis in a Mouse Model of Asthma. Stem Cells 34: 1836-1845. [Crossref]

66. Hermankova B, Zajicova A, Javorkova E, Chudickova M, Trosan P, et al. (2016) Suppression of IL-10 production by activated B cells via a cell contact-dependent cyclooxygenase-2 pathway upregulated in IFN-?-treated mesenchymal stem cells. Immunobiology 221: 129-136. [Crossref]

67. Kim HS, Shin TH, Lee BC, Yu KR, Seo Y, et al. (2013) Human umbilical cord blood mesenchymal stem cells reduce colitis in mice by activating NOD2 signaling to COX2. Gastroenterology 145: 1392-1403. [Crossref]

68. Kim HS, Yun JW, Shin TH, Lee SH, Lee BC, et al. (2015) Human umbilical cord blood mesenchymal stem cell-derived PGE2 and TGF- $\hat{I}^{2} 1$ alleviate atopic dermatitis by reducing mast cell degranulation. Stem Cells 33: 1254-1266. [Crossref]

69. Kochan G, Escors D, Breckpot K, Guerrero-Setas D (2013) Role of non-classical MHC class I molecules in cancer immunosuppression. Oncoimmunology 2: e26491. [Crossref]

70. Morandi F, Rouas-Freiss N, Pistoia V (2014) The emerging role of soluble HLA-G in the control of chemotaxis. Cytokine Growth Factor Rev 25: 327-335. [Crossref]

71. Amiot L, Vu N, Samson M (2015) Biology of the immunomodulatory molecule HLA-G in human liver diseases. $J$ Hepatol 62: 1430-1437. [Crossref]

72. Carosella ED, Moreau P, Le Maoult J, Le Discorde M, Dausset J, et al. (2003) HLA-G molecules: from maternal-fetal tolerance to tissue acceptance. Adv Immunol 81: 199252. [Crossref]

73. Rouas-Freiss N, Gonçalves RM, Menier C, Dausset J, Carosella ED (1997) Direct evidence to support the role of HLA-G in protecting the fetus from maternal uterine natural killer cytolysis. Proc Natl Acad Sci U S A 94: 11520-11525. [Crossref]

74. González A, Rebmann V, LeMaoult J, Horn PA, Carosella ED, et al. (2012) The immunosuppressive molecule HLA-G and its clinical implications. Crit Rev Clin Lab Sci 49: 63-84. [Crossref]

75. Selmani Z, Naji A, Zidi I, Favier B, Gaiffe E, et al. (2008) Human leukocyte antigen-G5 secretion by human mesenchymal stem cells is required to suppress $\mathrm{T}$ lymphocyte and natural killer function and to induce $\mathrm{CD} 4+\mathrm{CD} 25$ highFOXP3+ regulatory T cells. Stem Cells 26: 212-222. [Crossref]

76. Nasef A, Mathieu N, Chapel A, Frick J, François S, et al. (2007) Immunosuppressive effects of mesenchymal stem cells: involvement of HLA-G. Transplantation 84: 231237. [Crossref]

77. Rizzo R, Campioni D, Stignani M, Melchiorri L, Bagnara GP, et al. (2008) A functional role for soluble HLA-G antigens in immune modulation mediated by mesenchymal stromal cells. Cytotherapy 10: 364-375. [Crossref]

78. Rebmann V, König L, Nardi Fda S, Wagner B, Manvailer LF, et al. (2016) The Potential of HLA-G-Bearing Extracellular Vesicles as a Future Element in HLA-G Immune Biology. Front Immunol 7: 173. [Crossref]

79. Montespan F, Deschaseaux F, Sensébé L, Carosella ED, Rouas-Freiss N (2014) Osteodifferentiated mesenchymal stem cells from bone marrow and adipose tissue express HLA-G and display immunomodulatory properties in HLA-mismatched settings: implications in bone repair therapy. J Immunol Res 2014: 230346. [Crossref]

80. La Rocca G, Lo Iacono M, Corsello T, Corrao S, Farina F, et al. (2013) Human Wharton's jelly mesenchymal stem cells maintain the expression of key immunomodulatory molecules when subjected to osteogenic, adipogenic and chondrogenic differentiation in vitro: new perspectives for cellular therapy. Curr Stem Cell Res Ther 8: 100-113. [Crossref]

81. Caplan AI, Sorrell JM (2015) The MSC curtain that stops the immune system. Immunol Lett 168: 136-139. [Crossref]

82. Saldanha-Araujo F, Ferreira FI, Palma PV, Araujo AG, Queiroz RH, et al. (2011) Mesenchymal stromal cells up-regulate CD39 and increase adenosine production to suppress activated T-lymphocytes. Stem Cell Res 7: 66-74. [Crossref]
83. Sattler C, Steinsdoerfer M, Offers M, Fischer E, Schierl R, et al. (2011) Inhibition of T-cell proliferation by murine multipotent mesenchymal stromal cells is mediated by CD39 expression and adenosine generation. Cell Transplant 20: 1221-1230. [Crossref]

84. Alawad A, Altuwaijri S, Aljarbu A, Kryczek I, Niu Y, et al. (2015) Depletion of androgen receptor (AR) in mesenchymal stem cells (MSCs) inhibits induction of CD4+CD25+FOX3+ regulatory T (Treg) cells via androgen TGF- $\beta$ interaction. $J$ Appl Biomed 13: 263-271.

85. Markel TA, Crisostomo PR, Wang M, Herring CM, Meldrum DR (2007) Activation of individual tumor necrosis factor receptors differentially affects stem cell growth factor and cytokine production. Am J Physiol Gastrointest Liver Physiol 293: G657662. [Crossref]

86. Huang CK, Tsai MY, Luo J, Kang HY, Lee SO, et al. (2013) Suppression of androgen receptor enhances the self-renewal of mesenchymal stem cells through elevated expression of EGFR. Biochim Biophys Acta 1833:1222-1234. [Crossref]

87. Wu T, Liu Y, Fan Z, Xu J, Jin L, et al. (2015) miR-21 Modulates the Immunoregulatory Function of Bone Marrow Mesenchymal Stem Cells Through the PTEN/Akt/TGF- $\beta 1$ Pathway. Stem Cells 33: 3281-3290. [Crossref]

88. Barcellos-de-Souza P, Comito G, Pons-Segura C, Taddei ML, Gori V, et al. (2016) Mesenchymal Stem Cells are Recruited and Activated into Carcinoma-Associated Fibroblasts by Prostate Cancer Microenvironment-Derived TGF- $\beta 1$. Stem Cells: 2412. [Crossref]

89. Lee RH, Pulin AA, Seo MJ, Kota DJ, Ylostalo J, et al. (2009) Intravenous hMSCs improve myocardial infarction in mice because cells embolized in lung are activated to secrete the anti-inflammatory protein TSG-6. Cell Stem Cell 5: 54-63. [Crossref]

90. Oh JY, Roddy GW, Choi H, Lee RH, Ylöstalo JH, et al. (2010) Anti-inflammatory protein TSG-6 reduces inflammatory damage to the cornea following chemical and mechanical injury. Proc Natl Acad Sci U S A 107: 16875-16880. [Crossref]

91. Watanabe J, Shetty AK, Hattiangady B, Kim DK, Foraker JE, et al. (2013) Administration of TSG-6 improves memory after traumatic brain injury in mice. Neurobiol Dis 59: 86-99. [Crossref]

92. Qi Y, Jiang D, Sindrilaru A, Stegemann A, Schatz S, et al. (2014) TSG-6 released from intradermally injected mesenchymal stem cells accelerates wound healing and reduces tissue fibrosis in murine full-thickness skin wounds. J Invest Dermatol 134: 526-537. [Crossref]

93. Kota DJ, Wiggins LL, Yoon N, Lee RH (2013) TSG-6 produced by hMSCs delays the onset of autoimmune diabetes by suppressing Th1 development and enhancing tolerogenicity. Diabetes 62: 2048-2058. [Crossref]

94. Gao J, Dennis JE, Muzic RF, Lundberg M, Caplan AI (2001) The dynamic in vivo distribution of bone marrow-derived mesenchymal stem cells after infusion. Cells Tissues Organs 169: 12-20. [Crossref]

95. Roddy GW, Oh JY, Lee RH, Bartosh TJ, Ylostalo J, et al. (2011) Action at a distance: systemically administered adult stem/progenitor cells (MSCs) reduce inflammatory damage to the cornea without engraftment and primarily by secretion of TNF-a stimulated gene/protein 6. Stem Cells 29:1572-1579. [Crossref]

96. Choi H, Lee RH, Bazhanov N, Oh JY, Prockop DJ. (2011) Anti-inflammatory protein TSG-6 secreted by activated MSCs attenuates zymosan-induced mouse peritonitis by decreasing TLR2/NF-?B signaling in resident macrophages. Blood 118: 330-338 [Crossref]

97. Liang J, Jiang D, Griffith J, Yu S, Fan J, et al. (2007) CD44 is a negative regulator of acute pulmonary inflammation and lipopolysaccharide-TLR signaling in mouse macrophages. J Immunol 178: 2469-2475. [Crossref]

98. Kawana H, Karaki H, Higashi M, Miyazaki M, Hilberg F, et al. (2008) CD44 suppresses TLR-mediated inflammation. J Immunol 180: 4235-4245. [Crossref]

99. Lesley J, Gál I, Mahoney DJ, Cordell MR, Rugg MS, et al. (2004) TSG-6 modulates the interaction between hyaluronan and cell surface CD44. J Biol Chem 279: 25745 25754. [Crossref]

100. Dyer DP, Salanga CL, Johns SC, Valdambrini E, Fuster MM, et al. (2016) The Antiinflammatory Protein TSG-6 Regulates Chemokine Function by Inhibiting Chemokine/ Glycosaminoglycan Interactions. J Biol Chem 291: 12627-12640. [Crossref]

101. Martin J, Midgley A, Meran S, Woods E, Bowen T, et al. (2016) Tumor Necrosis Factor-stimulated Gene 6 (TSG-6)-mediated Interactions with the Inter-a-inhibitor Heavy Chain 5 Facilitate Tumor Growth Factor $\beta 1$ (TGF $\beta 1$ )-dependent Fibroblast to Myofibroblast Differentiation. J Biol Chem 291: 13789-13801. [Crossref]

102. Chau LY (2015) Heme oxygenase-1: emerging target of cancer therapy. J Biomed Sci 22: 22. [Crossref] 
103. Mougiakakos D, Jitschin R, Johansson CC, Okita R, Kiessling R, et al. (2011) The impact of inflammatory licensing on heme oxygenase-1-mediated induction of regulatory $\mathrm{T}$ cells by human mesenchymal stem cells. Blood 117: 4826-4835. [Crossref]

104. Chabannes D, Hill M, Merieau E, Rossignol J, Brion R, et al. (2007) A role for heme oxygenase-1 in the immunosuppressive effect of adult rat and human mesenchymal stem cells. Blood 110: 3691-3694. [Crossref]

105. Mangi AA, Noiseux N, Kong D, He H, Rezvani M, et al. (2003) Mesenchymal stem cells modified with Akt prevent remodeling and restore performance of infarcted hearts. Nat Med 9: 1195-1201. [Crossref]

106. Song H, Kwon K, Lim S, Kang SM, Ko YG, et al. (2005) Transfection of mesenchyma stem cells with the FGF-2 gene improves their survival under hypoxic conditions. Mol Cells 19: 402-407. [Crossref]

107. Wu B, Song HL, Yang Y, Yin ML, Zhang BY, et al. (2016) Improvement of Liver Transplantation Outcome by Heme Oxygenase-1-Transduced Bone Marrow Mesenchymal Stem Cells in Rats. Stem Cells Int 2016: 9235073. [Crossref]

108. Patel SR, Copland IB, Garcia MA, Metz R, Galipeau J (2015) Human mesenchymal stromal cells suppress T-cell proliferation independent of heme oxygenase-1. Cytotherapy 17: 382-391. [Crossref]

109. Rafei M, Campeau PM, Aguilar-Mahecha A, Buchanan M, Williams P, et al. (2009) Mesenchymal stromal cells ameliorate experimental autoimmune encephalomyelitis by inhibiting CD4 Th17 T cells in a CC chemokine ligand 2-dependent manner. $J$ Immunol 182: 5994-6002. [Crossref]

110. McQuibban GA, Gong JH, Wong JP, Wallace JL, Clark-Lewis I, et al. (2002) Matrix metalloproteinase processing of monocyte chemoattractant proteins generates $\mathrm{CC}$ chemokine receptor antagonists with anti-inflammatory properties in vivo. Blood 100 : 1160-1167. [Crossref]

111. Rafei M, Hsieh J, Fortier S, Li M, Yuan S, et al. (2008) Mesenchymal stromal cell-derived CCL2 suppresses plasma cell immunoglobulin production via STAT3 inactivation and PAX5 induction. Blood 112: 4991-4998. [Crossref]

112. Lee HJ, Ko JH, Jeong HJ, Ko AY, Kim MK, et al. (2015) Mesenchymal stem/stromal cells protect against autoimmunity via CCL2-dependent recruitment of myeloidderived suppressor cells. J Immunol 194: 3634-3645. [Crossref]

113. Che N, Li X, Zhang L, Liu R, Chen H, et al. (2014) Impaired B cell inhibition by lupus bone marrow mesenchymal stem cells is caused by reduced CCL2 expression. $J$ Immunol 193: 5306-5314. [Crossref]

114. Zhou Y, Day A, Haykal S, Keating A, Waddell TK (2013) Mesenchymal stromal cells augment CD4+ and CD8+ T-cell proliferation through a CCL2 pathway. Cytotherapy 15: 1195-1207. [Crossref]

115. Beyth S, Borovsky Z, Mevorach D, Liebergall M, Gazit Z, et al. (2005) Human mesenchymal stem cells alter antigen-presenting cell maturation and induce T-cell unresponsiveness. Blood 105: 2214-2219. [Crossref]

116. Del Papa B, Sportoletti P, Cecchini D, Rosati E, Balucani C, et al. (2013) Notch1 modulates mesenchymal stem cells mediated regulatory T-cell induction. Eur $J$ Immunol 43: 182-187. [Crossref]

117. Liotta F, Angeli R, Cosmi L, Filì L, Manuelli C, et al. (2008) Toll-like receptors 3 and 4 are expressed by human bone marrow-derived mesenchymal stem cells and can inhibit their T-cell modulatory activity by impairing Notch signaling. Stem Cells 26: 279-289. [Crossref]

118. Zhang B, Liu R, Shi D, Liu X, Chen Y, et al. (2009) Mesenchymal stem cells induce mature dendritic cells into a novel Jagged-2-dependent regulatory dendritic cell population. Blood 113: 46-57. [Crossref]

119. Xishan Z, Bin Z, Haiyue Z, Xiaowei D, Jingwen B, et al. (2015) Jagged-2 enhances immunomodulatory activity in adipose derived mesenchymal stem cells. Sci Rep 5: 14284. [Crossref]

120. Ren G, Zhao X, Zhang L, Zhang J, L'Huillier A, et al. (2010) Inflammatory cytokineinduced intercellular adhesion molecule- 1 and vascular cell adhesion molecule-1 in mesenchymal stem cells are critical for immunosuppression. J Immunol 184: 23212328. [Crossref]

121. Jiang D, Muschhammer J, Qi Y, Kügler A, de Vries JC, et al. (2016) Suppression of Neutrophil-Mediated Tissue Damage-A Novel Skill of Mesenchymal Stem Cells. Stem Cells.

122. Aomatsu E, Takahashi N, Sawada S, Okubo N, Hasegawa T, et al. (2014) Novel SCRG1/BST1 axis regulates self-renewal, migration, and osteogenic differentiation potential in mesenchymal stem cells. Sci Rep 4: 3652. [Crossref]
123. Honczarenko M, Le Y, Swierkowski M, Ghiran I, Glodek AM, et al. (2006) Human bone marrow stromal cells express a distinct set of biologically functional chemokine receptors. Stem Cells 24: 1030-1041. [Crossref]

124. Mabuchi Y, Morikawa S, Harada S, Niibe K, Suzuki S, et al. (2013) LNGFR(+)THY$1(+)$ VCAM-1(hi+) cells reveal functionally distinct subpopulations in mesenchymal stem cells. Stem Cell Reports 1: 152-165. [Crossref]

125. Rabinovich GA, Toscano MA (2009) Turning 'sweet' on immunity: galectin-glycan interactions in immune tolerance and inflammation. Nat Rev Immunol 9: 338-352. [Crossref]

126. Kadri T, Lataillade JJ, Doucet C, Marie A, Ernou I, et al. (2005) Proteomic study of Galectin-1 expression in human mesenchymal stem cells. Stem Cells Dev 14: 204-212. [Crossref]

127. Silva WA Jr, Covas DT, Panepucci RA, Proto-Siqueira R, Siufi JL, et al. (2003) The profile of gene expression of human marrow mesenchymal stem cells. Stem Cells 21: 661-669. [Crossref]

128. Lepelletier Y, Lecourt S, Renand A, Arnulf B, Vanneaux V, et al. (2010) Galectin-1 and semaphorin-3A are two soluble factors conferring T-cell immunosuppression to bone marrow mesenchymal stem cell. Stem Cells Dev 19: 1075-1079. [Crossref]

129. Gieseke F, Böhringer J, Bussolari R, Dominici M, Handgretinger R, et al. (2010) Human multipotent mesenchymal stromal cells use galectin-1 to inhibit immune effector cells. Blood 116: 3770-3779. [Crossref]

130. Toscano MA, Bianco GA, Ilarregui JM, Croci DO, Correale J, et al. (2007) Differential glycosylation of TH1, TH2 and TH-17 effector cells selectively regulates susceptibility to cell death. Nat Immunol 8: 825-834. [Crossref]

131. Fajka-Boja R, Urbán VS, Szebeni GJ, Czibula Á, Blaskó A, et al. (2016) Galectin-1 is a local but not systemic immunomodulatory factor in mesenchymal stromal cells. Cytotherapy 18: 360-370. [Crossref]

132. Prasanna SJ, Gopalakrishnan D, Shankar SR, Vasandan AB (2010) Pro-inflammatory cytokines, IFNgamma and TNFalpha, influence immune properties of human bone marrow and Wharton jelly mesenchymal stem cells differentially. PLoS One 5: e9016. [Crossref]

133. Yen BL, Yen ML, Hsu PJ, Liu KJ, Wang CJ, et al. (2013) Multipotent human mesenchymal stromal cells mediate expansion of myeloid-derived suppressor cells via hepatocyte growth factor/c-met and STAT3. Stem Cell Reports 1: 139-151. [Crossref]

134. Chen PM, Liu KJ, Hsu PJ, Wei CF, Bai CH, et al. (2014) Induction of immunomodulatory monocytes by human mesenchymal stem cell-derived hepatocyte growth factor through ERK1/2. J Leukoc Biol 96: 295-303. [Crossref]

135. Cao XP, Han DM, Zhao L, Guo ZK, Xiao FJ, et al. (2016) Hepatocyte growth factor enhances the inflammation-alleviating effect of umbilical cord-derived mesenchymal stromal cells in a bronchiolitis obliterans model. Cytotherapy 18: 402-412. [Crossref]

136. Wang H, Sun RT, Li Y, Yang YF, Xiao FJ, et al. (2015) HGF Gene Modification in Mesenchymal Stem Cells Reduces Radiation-Induced Intestinal Injury by Modulating Immunity. PLoS One 10: e124420. [Crossref]

137. Hu S, Li J, Xu X, Liu A, He H, et al. (2016) The hepatocyte growth factor-expressing character is required for mesenchymal stem cells to protect the lung injured by lipopolysaccharide in vivo. Stem Cell Res Ther 7: 66. [Crossref]

138. Augello A, Tasso R, Negrini SM, Amateis A, Indiveri F, et al. (2005) Bone marrow mesenchymal progenitor cells inhibit lymphocyte proliferation by activation of the programmed death 1 pathway. Eur J Immunol 35: 1482-1490. [Crossref]

139. Sheng H, Wang Y, Jin Y, Zhang Q, Zhang Y, et al. (2008) A critical role of IFNgamma in priming MSC-mediated suppression of $\mathrm{T}$ cell proliferation through up-regulation of B7-H1. Cell Res 18: 846-857. [Crossref]

140. Luan X, Li G, Wang G, Wang F, Lin Y (2013) Human placenta-derived mesenchymal stem cells suppress $\mathrm{T}$ cell proliferation and support the culture expansion of cord blood CD34? cells: a comparison with human bone marrow-derived mesenchymal stem cells. Tissue Cell 45:32-38. [Crossref]

141. Li H, Wang W, Wang G, Hou Y, Xu F, et al. (2015) Interferon-? and tumor necrosis factor-a promote the ability of human placenta-derived mesenchymal stromal cells to express programmed death ligand-2 and induce the differentiation of CD4(+) interleukin-10(+) and CD8(+)interleukin-10(+)Treg subsets. Cytotherapy 17: 15601571. [Crossref]

142. Wang WB, Yen ML, Liu KJ, Hsu PJ, Lin MH, et al. (2015) Interleukin-25 Mediates Transcriptional Control of PD-L1 via STAT3 in Multipotent Human Mesenchymal Stromal Cells (hMSCs) to Suppress Th17 Responses. Stem Cell Reports 5: 392-404 [Crossref] 
143. Akiyama K, Chen C, Wang D, Xu X, Qu C, et al. (2012) Mesenchymal-stem-cellinduced immunoregulation involves FAS-ligand-/FAS-mediated T cell apoptosis. Cell Stem Cell 10: 544-555. [Crossref]

144. Gu YZ, Xue Q, Chen YJ, Yu GH, Qing MD, et al. (2013) Different roles of PD-L1 and FasL in immunomodulation mediated by human placenta-derived mesenchymal stem cells. Hum Immunol 74: 267-276. [Crossref]

145. Lindsay SL, Johnstone SA, McGrath MA, Mallinson D, Barnett SC (2016) Comparative miRNA-Based Fingerprinting Reveals Biological Differences in Human Olfactory Mucosa- and Bone-Marrow-Derived Mesenchymal Stromal Cells. Stem Cell Reports 6: 729-742. [Crossref]

146. Vallabhaneni KC, Penfornis P, Dhule S, Guillonneau F, Adams KV, et al. (2015) Extracellular vesicles from bone marrow mesenchymal stem/stromal cells transport tumor regulatory microRNA, proteins, and metabolites. Oncotarget 6: 4953-4967. [Crossref]

147. Zhao X, Liu D, Gong W, Zhao G, Liu L, et al. (2014) The toll-like receptor 3 ligand, poly(I:C), improves immunosuppressive function and therapeutic effect of mesenchymal stem cells on sepsis via inhibiting MiR-143. Stem Cells 32: 521-533. [Crossref]

148. Rolfo A, Giuffrida D, Nuzzo AM, Pierobon D, Cardaropoli S, et al. (2013) Proinflammatory profile of preeclamptic placental mesenchymal stromal cells: new insights into the etiopathogenesis of preeclampsia. PLoS One 8: e59403. [Crossref]

149. Wang Y, Fan H, Zhao G, Liu D, Du L, et al. (2012) miR-16 inhibits the proliferation and angiogenesis-regulating potential of mesenchymal stem cells in severe preeclampsia. FEBS J 279: 4510-4524. [Crossref]

150. Chen S, Zhao G, Miao H, Tang R, Song Y, et al. (2015) MicroRNA-494 inhibits the growth and angiogenesis-regulating potential of mesenchymal stem cells. FEBS Lett 589: 710-717. [Crossref]

151. Liu L, Wang Y, Fan H, Zhao X, Liu D, et al. (2012) MicroRNA-181a regulates loca immune balance by inhibiting proliferation and immunosuppressive properties of mesenchymal stem cells. Stem Cells 30: 1756-1770. [Crossref]

152. Shao B, Liao L, Yu Y, Shuai Y, Su X, et al. (2015) Estrogen preserves Fas ligand levels by inhibiting microRNA-181a in bone marrow-derived mesenchymal stem cells to maintain bone remodeling balance. FASEB J 29: 3935-3944. [Crossref]

153. Comer BS, Camoretti-Mercado B, Kogut PC, Halayko AJ, Solway J, et al. (2014) MicroRNA-146a and microRNA-146b expression and anti-inflammatory function in human airway smooth muscle. Am J Physiol Lung Cell Mol Physiol 307: L727-734. [Crossref]

154. Oikonomopoulos A, Polytarchou C, Hatziapostolou M, Koukow G, Hommes DW (2015) Inhibition of microRNA-29a in human bone marrow mesenchymal stem cells augments their immunosuppressive properties. J of Crohn's and Colitis 9: S106

155. Najar M, Raicevic G, Jebbawi F, De Bruyn C, Meuleman N, et al. (2012) Characterization and functionality of the CD200-CD200R system during mesenchymal stromal cell interactions with T-lymphocytes. Immunol Lett 146: 50-56. [Crossref]

156. Picarda E, Ohaegbulam KC, Zang X (2016) Molecular Pathways: Targeting B7H3 (CD276) for Human Cancer Immunotherapy. Clin Cancer Res 22: 3425-3431. [Crossref]

157. Ortiz LA, Dutreil M, Fattman C, Pandey AC, Torres G, et al. (2007) Interleukin 1 receptor antagonist mediates the antiinflammatory and antifibrotic effect of mesenchymal stem cells during lung injury. Proc Natl Acad Sci U S A 104: 11002 11007. [Crossref]

158. Luz-Crawford P, Djouad F, Toupet K, Bony C, Franquesa M, et al. (2016) Mesenchymal Stem Cell-Derived Interleukin 1 Receptor Antagonist Promotes Macrophage Polarization and Inhibits B Cell Differentiation. Stem Cells 34: 483-492. [Crossref]

159. Munir H, Luu NT, Clarke LS, Nash GB, McGettrick HM (2016) Comparative Ability of Mesenchymal Stromal Cells from Different Tissues to Limit Neutrophil Recruitment to Inflamed Endothelium. PLoS One 11: e0155161. [Crossref]

160. Djouad F, Charbonnier LM, Bouffi C, Louis-Plence P, Bony C, et al. (2007) Mesenchymal stem cells inhibit the differentiation of dendritic cells through an interleukin-6-dependent mechanism. Stem Cells 25: 2025-2032. [Crossref]

161. Zanotti L, Angioni R, Calì B, Soldani C, Ploia C, et al. (2016) Mouse mesenchymal stem cells inhibit high endothelial cell activation and lymphocyte homing to lymph nodes by releasing TIMP-1. Leukemia 30: 1143-1154. [Crossref]

162. NasefA, Mazurier C, Bouchet S, François S, ChapelA, et al. (2008) Leukemia inhibitory factor: Role in human mesenchymal stem cells mediated immunosuppression. Cell Immunol 253: 16-22. [Crossref]
163. Najar M, Raicevic G, Boufker HI, Fayyad-Kazan H, De Bruyn C, et al. (2010) Adipose-tissue-derived and Wharton's jelly-derived mesenchymal stromal cells suppress lymphocyte responses by secreting leukemia inhibitory factor. Tissue Eng Part A 16: 3537-3546. [Crossref]

164. Covas DT, Siufi JL, Silva AR, Orellana MD (2003) Isolation and culture of umbilical vein mesenchymal stem cells. Braz J Med Biol Res 36: 1179-1183. [Crossref]

165. Panepucci RA, Siufi JL, Silva WA Jr, Proto-Siquiera R, Neder L, et al. (2004) Comparison of gene expression of umbilical cord vein and bone marrow-derived mesenchymal stem cells. Stem Cells 22: 1263-1278. [Crossref]

166. Weiss ML, Anderson C, Medicetty S, Seshareddy KB, Weiss RJ, et al. (2008) Immune properties of human umbilical cord Wharton's jelly-derived cells. Stem Cells 26 2865-2874. [Crossref]

167. Valencic E, Piscianz E, Andolina M, Ventura A, Tommasini A (2010) The immunosuppressive effect of Wharton's jelly stromal cells depends on the timing of their licensing and on lymphocyte activation. Cytotherapy 12: 154-160. [Crossref]

168. Mancheño-Corvo P, Menta R, del Río B, Franquesa M, Ramírez C, et al. (2015) T Lymphocyte Prestimulation Impairs in a Time-Dependent Manner the Capacity of Adipose Mesenchymal Stem Cells to Inhibit Proliferation: Role of Interferon ? Poly I:C, and Tryptophan Metabolism in Restoring Adipose Mesenchymal Stem Cell Inhibitory Effect. Stem Cells Dev 24: 2158-2170. [Crossref]

169. Krampera M, Cosmi L, Angeli R, Pasini A, Liotta F, et al. (2006) Role for interferongamma in the immunomodulatory activity of human bone marrow mesenchymal stem cells. Stem Cells 24: 386-398. [Crossref]

170. English K, Barry FP, Field-Corbett CP, Mahon BP (2007) IFN-gamma and TNFalpha differentially regulate immunomodulation by murine mesenchymal stem cells. Immunol Lett 110: 91-100. [Crossref]

171. Polchert D, Sobinsky J, Douglas G, Kidd M, Moadsiri A, et al. (2008) IFN-gamma activation of mesenchymal stem cells for treatment and prevention of graft versus host disease. Eur J Immunol 38: 1745-1755. [Crossref]

172. Ghannam S, Bouffi C, Djouad F, Jorgensen C, Noël D (2010) Immunosuppression by mesenchymal stem cells: mechanisms and clinical applications. Stem Cell Res The 1: 2 . [Crossref]

173. Crop MJ, Baan CC, Korevaar SS, Ijzermans JN, Pescatori M, et al. (2010) Inflammatory conditions affect gene expression and function of human adipose tissuederived mesenchymal stem cells. Clin Exp Immunol 162: 474-486. [Crossref]

174. Waterman RS, Tomchuck SL, Henkle SL, Betancourt AM (2010) A new mesenchymal stem cell (MSC) paradigm: polarization into a pro-inflammatory MSC1 or an Immunosuppressive MSC2 phenotype. PLoS One 5: e10088. [Crossref]

175. Sangiorgi B, De Freitas HT, Schiavinato JL, Leão V, Haddad R, et al. (2016) DSP30 enhances the immunosuppressive properties of mesenchymal stromal cells and protects their suppressive potential from lipopolysaccharide effects: A potential role of adenosine. Cytotherapy 18: 846-859. [Crossref]

176. Opitz CA, Litzenburger UM, Lutz C, Lanz TV, Tritschler I, et al. (2009) Toll-like receptor engagement enhances the immunosuppressive properties of human bone marrow-derived mesenchymal stem cells by inducing indoleamine-2,3-dioxygenase-1 via interferon- $\beta$ and protein kinase R. Stem Cells 27: 909-919. [Crossref]

177. Fuenzalida P, Kurte M, Fernández-O'ryan C, Ibañez C, Gauthier-Abeliuk M, et al (2016) Toll-like receptor 3 pre-conditioning increases the therapeutic efficacy of umbilical cord mesenchymal stromal cells in a dextran sulfate sodium-induced colitis model. Cytotherapy 18: 630-641. [Crossref]

178. Huang S, Wang D, Gu F, Zhang Z, Deng W, et al. (2016) No significant effects of Poly(I:C) on human umbilical cord-derived mesenchymal stem cells in the treatment of B6.MRL-Fas(lpr) mice. Curr Res Transl Med 64: 55-60. [Crossref]

179. Zhang L, Liu D, Pu D, Wang Y, Li L, et al. (2015) The role of Toll-like receptor 3 and 4 in regulating the function of mesenchymal stem cells isolated from umbilical cord. Int J Mol Med 35: 1003-1010. [Crossref]

180. Giuliani M, Bennaceur-Griscelli A, Nanbakhsh A, Oudrhiri N, Chouaib S, et al. (2014) TLR ligands stimulation protects MSC from NK killing. Stem Cells 32: 290-300. [Crossref]

181. Fang X, Abbott J, Cheng L, Colby JK, Lee JW, et al. (2015) Human Mesenchyma Stem (Stromal) Cells Promote the Resolution of Acute Lung Injury in Part through Lipoxin A4. J Immunol 195: 875-88. [Crossref]

182. Wang B, Yao K, Huuskes BM, Shen HH, Zhuang J, et al. (2016) Mesenchymal Stem Cells Deliver Exogenous MicroRNA-let7c via Exosomes to Attenuate Renal Fibrosis. Mol Ther. [Crossref] 
Nishizawa K (2016) Mechanisms of immunosuppression by mesenchymal stromal cells: a review with a focus on molecules

183. Quaranta P, Focosi D, Di Iesu M, Cursi C, Zucca A, et al. (2016) Human Wharton's jelly-derived mesenchymal stromal cells engineered to secrete Epstein-Barr virus interleukin-10 show enhanced immunosuppressive properties. Cytotherapy 18: 205218. [Crossref]

Copyright: (C2016 Nishizawa K. This is an open-access article distributed under the terms of the Creative Commons Attribution License, which permits unrestricted use, distribution, and reproduction in any medium, provided the original author and source are credited. 